\title{
IRON AGE MEDITERRANEAN CHRONOLOGY: A REPLY
}

\author{
Hendrik J Bruins ${ }^{1}$ - Albert J Nijboer ${ }^{2}$ Johannes van der Plicht ${ }^{3}$
}

\begin{abstract}
This article is a reply to the preceding rejoinder by Fantalkin et al., which they wrote in response to our article concerning radiocarbon dates of Iron Age sites in the Mediterranean region measured at Groningen (van der Plicht et al. 2009). We do not agree with much of their criticism. Our reply is presented in detail with new viewpoints and evaluations concerning a number of sites in the Levant, including Tel Dan, Megiddo Stratum VIA (=K/4), Horvat Haluqim, Tell el-Qudeirat, Khirbet en-Nahas, Tel Rehov, as well as sites in the central and western Mediterranean region, particularly Carthage and Huelva. Our main conclusions are that ${ }^{14} \mathrm{C}$ dating supports an Iron Age High Chronology for the above sites, though more ${ }^{14} \mathrm{C}$ dating is required, particularly in Greece and the central and western Mediterranean region, to substantiate and refine the current state of knowledge. We prefer detailed investigations per individual site, evaluating both ${ }^{14} \mathrm{C}$ dates and site stratigraphy, rather than the wholesale averaging of strata over many sites, which may lead to oversimplification and erroneous results, also on stratigraphic grounds. Contrary to Fantalkin et al. (2011), we emphasize the importance of ${ }^{14} \mathrm{C}$ dating as an independent methodology — chronostratigraphy — to evaluate site stratigraphy. The ${ }^{14} \mathrm{C}$ dates of Megiddo Stratum VIA (=K/4) clearly indicate field-stratigraphic problems at this site.
\end{abstract}

\section{INTRODUCTION}

Our reply follows more or less the outline of the rejoinder by Fantalkin et al. (2011). Thus, we begin with the Levant, discussing in detail Tel Dan, including Megiddo Stratum VIA (K/4), which is related by all authorities to Dan Stratum V. Many new data are presented from the rural site of Horvat Haluqim, situated in the central Negev Desert, also evaluating the issue of runoff farming in the Iron Age. New interpretations are presented concerning the important desert site of Tell el-Qudeirat, situated in NE Sinai $\sim 50 \mathrm{~km} \mathrm{SW}$ of Horvat Haluqim. We also discuss the criticism by Fantalkin et al. regarding the desert site of Khirbet en-Nahas in Jordan and the key Iron Age site of Tel Rehov.

Subsequently, the sites in the central and western Mediterranean region are discussed. First, an outline is given of the important chronological relationships between Italy and central Europe, where Iron Age dates based on dendrochronology led to an older chronology. The sites of Carthage and Huelva are discussed in detail, also with respect to archaeological and historical data for Greece and Phoenicia. The radiocarbon dates of Achziv-Huelva fibula contexts, having a wide distribution in the Mediterranean region, are emphasized. The important ${ }^{14} \mathrm{C}$ dates from Megiddo, measured in the context of the large Iron Age dating project by Sharon et al. (2007), underline the value of ${ }^{14} \mathrm{C}$ dating as an independent chronostratigraphic methodology.

\section{THE LEVANT}

\section{Tel Dan}

The perspective of Fantalkin et al. (2011:179) is characterized by their opening sentence: "Tel Dan cannot be part of a significant chronology discussion because its stratigraphy is chaotic." Thus, the authors discount the many years of archaeological excavations at Tel Dan conducted by the late Avraham Biran and his team. We do not accept this statement. They quote from the PhD dissertation by Ilan (1999) in an attempt to back up their judgment. The last part of the quotation reads: “...stratigraphic resolution is not always sharp as might be expected" (Ilan 1999:28). Indeed, there is hardly

\footnotetext{
${ }^{1}$ Ben Gurion University of the Negev, Jacob Blaustein Institutes for Desert Research, Sede Boker Campus \& Department of Bible, Archaeology, and Ancient Near Eastern Studies, Beer Sheva Campus, Israel.

${ }^{2}$ Institute for Archaeology, Groningen University, Groningen, the Netherlands.

${ }^{3}$ Center for Isotope Research, Groningen University, Groningen, the Netherlands. Also: Faculty of Archaeology, Leiden University, Leiden, the Netherlands.
} 
a mound or an excavation where the stratigraphic resolution is always sharp, not even at Megiddo, as will be demonstrated below, but in our opinion to interpret the words by Ilan (1999) as if he suggested that the stratigraphy at Tel Dan is chaotic is a distortion of reality. Ilan takes the stratigraphy of Tel Dan seriously throughout his dissertation. For example, his opening sentence of the section on relative chronology is as follows (Ilan 1999:137): "The wealth of ceramic, architectural and behavioral parallels would appear to make the construction of a relative chronology a fairly straightforward exercise." Subsequently, he presents a comparative chronological table in which he correlates Tel Dan strata VIIA, VI, V, IVB, and IVA with 17 other archaeological sites.

The name for Tel Dan in Arabic is Tell el-Qadi, meaning the "Mount of the Judge" (Biran 1994:21). Indeed, judged by the available ${ }^{14} \mathrm{C}$ dates of Tel Dan, the results (Table 1) are incompatible with a Low Chronology, but do support a High Conventional Chronology for the Iron Age (Bruins et al. 2005a; van der Plicht et al. 2009).

Tel Dan Stratum IVA is archaeologically dated by Biran (1994:11) from the second half of the 10th to the beginning of the 9th century BCE and by Ilan (1999:137) from 950 BCE, similarly as Biran, but ending lower in the 9th century at 850 BCE. Dan Stratum IVA is correlated with Megiddo VAIVB by both Ilan (1999) and Finkelstein (1999:63), who places the destruction of these strata around 850 BCE. The duration of Dan IVA, which Finkelstein (1999) correlates with Hazor IX, is dated in his young chronology perspective to 900-850 BCE.

Table 1 shows the ${ }^{14} \mathrm{C}$ result of a short-lived sample (GrA-9659) of olive pits from Dan Stratum IVA, with a 1- $\sigma$ calibrated age of 1050-914 BCE. This result is clearly incompatible with the Finkelstein (1999) Low Chronology and supports a High Chronology for the Iron Age. See also the archaeological objections by Ben-Tor (2000) against the Low Chronology of Finkelstein concerning sites in northern Israel.

The older Stratum V of Tel Dan is dated by Biran (1994:11) on archaeological considerations to the period 1200-1050 BCE and by Ilan (1999:137) to the period 1150-1050 BCE. Finkelstein (1999) proposed a much lower date of 1000-900 BCE for Tel Dan Stratum V in his Low Chronology perspective of Iron Age strata at archaeological sites in northern Israel. He correlated Dan V with Megiddo VIA, Yoqneam XVII, Bet-shean Upper VI, Tel Hadar IV, and Tell el-Oreimeh V, which all have similar pottery assemblages, dating, according to him, to the 10th century BCE (Finkelstein 1999:67).

Table 1 shows the ${ }^{14} \mathrm{C}$ dates of 11 samples in destruction layers from Tel Dan Stratum V, derived from 7 different loci (Bruins et al. 2005a; van der Plicht et al. 2009). Note that the Groningen Center for Isotope Research has both a conventional ${ }^{14} \mathrm{C}$ lab (based on proportional gas counting - PGC) and an accelerator mass spectrometry (AMS) facility (van der Plicht et al. 2000; van der Plicht and Bruins 2001). Seven PGC dates of Tel Dan have a very high precision with a standard deviation of only $15 \mathrm{yr}$ BP ( 5 dates) or $20 \mathrm{yr}$ BP (2 dates). The short-lived sample of charred olive pits (GrA$9624,2930 \pm 50$ BP) in destruction debris on a tamped earth floor in Area Y, Phase 6, has a 1- $\sigma$ calibrated range of 1250-1051 BCE. This result fits very well indeed with the archaeological age assessment of Biran (1994) for Stratum V: 1200-1050 BCE. On the other hand, the result is incompatible with the Finkelstein (1999) younger chronology, in which Stratum V is supposed to have an age of $1000-900 \mathrm{BCE}$, which is $\sim 200$ yr younger than the above short-lived ${ }^{14} \mathrm{C}$ date.

The other $10{ }^{14} \mathrm{C}$ dates of Stratum V in Table 1 are from charcoal samples. Fantalkin et al. (2011) simply dismiss the ${ }^{14} \mathrm{C}$ dates from Tel Dan, because many are based on charcoal, while some dating results led to a reevaluation of the initial field stratigraphic assignment. Concerning the latter issue, 
Table 1 Tel Dan ${ }^{14} \mathrm{C}$ dates in comparison to the conventional High Chronology (Biran 1994) and the Low Chronology (Finkelstein 1999).

\begin{tabular}{|c|c|c|c|c|c|c|c|c|}
\hline $\begin{array}{l}\text { Tel Dan } \\
\text { Stratum }\end{array}$ & $\begin{array}{l}\text { Area \& } \\
\text { phase }\end{array}$ & Locus & $\begin{array}{l}\text { Archaeo. } \\
\text { period }\end{array}$ & $\begin{array}{l}\text { Biran (1994) } \\
\text { Conventional } \\
\text { High Chronology } \\
\text { BCE }\end{array}$ & $\begin{array}{l}\text { Finkelstein } \\
\text { (1999) Low } \\
\text { Chronology } \\
\text { BCE }\end{array}$ & $\begin{array}{l}\text { Material \& } \\
\text { Groningen } \\
\text { lab nr }\end{array}$ & $\begin{array}{l}{ }^{14} \mathrm{C} \text { date } \\
(1 \sigma) \\
\text { yr BP }\end{array}$ & $\begin{array}{l}\text { Calibrated } \\
\text { date }(1 \sigma) \\
\text { BCE }\end{array}$ \\
\hline IVA & $\begin{array}{l}\mathrm{B} \\
6-7\end{array}$ & $570 a$ & Iron IIA & $950-875$ & $900-850$ & $\begin{array}{l}\text { Olive pits } \\
\text { GrA-9659 }\end{array}$ & $2830 \pm 50$ & $1050-914$ \\
\hline IVB & $\begin{array}{l}\text { A-B } \\
\text { B8 }\end{array}$ & 7114 & Iron IB & $1050-950$ & & $\begin{array}{l}\text { Charcoal } \\
\text { GrN-22518 }\end{array}$ & $2945 \pm 15$ & $1208-1125$ \\
\hline V & $\begin{array}{l}\mathrm{Y} \\
6\end{array}$ & 3024 & Iron IA & $1200-1050$ & $1000-900$ & & $2930 \pm 50$ & $1250-1051$ \\
\hline V & $\begin{array}{l}\mathrm{B} \\
10\end{array}$ & 1204 & Iron IA & $1200-1050$ & $1000-900$ & & $2930 \pm 50$ & $1250-1051$ \\
\hline V & $\begin{array}{l}\text { B } \\
9-10\end{array}$ & $\begin{array}{l}593 \\
(624)\end{array}$ & Iron IA & $1200-1050$ & $1000-900$ & $\begin{array}{l}\text { Charcoal } \\
\text { GrN-22523 }\end{array}$ & $2960 \pm 15$ & $1253-1129$ \\
\hline V & $\begin{array}{l}\text { B } \\
9-10\end{array}$ & 675 & Iron IA & $1200-1050$ & $1000-900$ & $\begin{array}{l}\text { Charcoal } \\
\text { GrN-22530 }\end{array}$ & $2965 \pm 15$ & $1256-1130$ \\
\hline V & $\begin{array}{l}\mathrm{B} \\
9-10\end{array}$ & 675 & Iron IA & $1200-1050$ & $1000-900$ & $\begin{array}{l}\text { Charcoal } \\
\text { GrN-22526 }\end{array}$ & $2980 \pm 15$ & $1262-1133$ \\
\hline V & $\begin{array}{l}\text { A-B } \\
\text { B9-10 }\end{array}$ & 7147 & Iron IA & $1200-1050$ & $1000-900$ & $\begin{array}{l}\text { Charcoal } \\
\text { GrN-22517 }\end{array}$ & $2985 \pm 20$ & $1266-1132$ \\
\hline V & $\begin{array}{l}\mathrm{B} \\
9-10\end{array}$ & $\begin{array}{l}593 \\
(694)\end{array}$ & Iron IA & $1200-1050$ & $1000-900$ & $\begin{array}{l}\text { Charcoal } \\
\text { GrN-22527 }\end{array}$ & $2990 \pm 15$ & $1287-1134$ \\
\hline V & $\begin{array}{l}\text { B } \\
9-10\end{array}$ & $\begin{array}{l}593 \\
(624)\end{array}$ & Iron IA & $1200-1050$ & $1000-900$ & $\begin{array}{l}\text { Charcoal } \\
\text { GrN-22967 }\end{array}$ & $2995 \pm 20$ & $1293-1210$ \\
\hline V & $\begin{array}{l}\mathrm{B} \\
9-10\end{array}$ & $\begin{array}{l}593 \\
(624)\end{array}$ & Iron IA & $1200-1050$ & $1000-900$ & $\begin{array}{l}\text { Charcoal } \\
\text { GrN-22524 }\end{array}$ & $3000 \pm 30$ & 1309-1133 \\
\hline V & $\begin{array}{l}\text { B } \\
9-10\end{array}$ & 660 & Iron IA & $1200-1050$ & $1000-900$ & $\begin{array}{l}\text { Charcoal } \\
\text { GrN-22525 }\end{array}$ & $3000 \pm 30$ & $1309-1133$ \\
\hline V & $\begin{array}{l}\text { B } \\
9-10\end{array}$ & 7208 & Iron IA & $1200-1050$ & $1000-900$ & $\begin{array}{l}\text { Charcoal } \\
\text { GrA-9618 }\end{array}$ & $3020 \pm 50$ & $1380-1210$ \\
\hline
\end{tabular}

${ }^{\mathrm{a}} \mathrm{GrN}$ sample code refers to Groningen conventional ${ }^{14} \mathrm{C}$ dates measured by PGC; GrA code refers to samples measured in Groningen by AMS. Calibration curved used: Reimer et al. 2004; all dates are calibrated with OxCal v3.10, Bronk Ramsey 2001, 2005.

it is a normal phenomenon in stratigraphic investigations, both in geology and archaeology, that the addition of ${ }^{14} \mathrm{C}$ dating to the existing methods will lead to a refinement, and sometimes a revision, of field-stratigraphic understandings. Moreover, the definition of a "stratum" in archaeological excavations is not always as clear as one would like due to inherent field-stratigraphic complexities and variability in the corpus of "type fossils," i.e. the material culture. It is shown below that the stratigraphy of Megiddo Stratum K/4 = VIA (Finkelstein et al. 2008) has to be reevaluated in view of the ${ }^{14} \mathrm{C}$ dates by Sharon et al. (2007).

In our view, the approach by Fantalkin et al. (2011) to erase any charcoal date is not justified in scientific terms. Short-lived seeds are generally preferable, but not always available in sufficient amounts, as was the case for Tel Dan. Nevertheless, the 10 charcoal dates from Stratum V (Table 1) are all very consistent. The old-wood factor in charcoal from a tree can range from zero to tens or scores of years, but rarely hundreds of years. Indeed, 1 charcoal date (GrA-9616, $2930 \pm 50 \mathrm{BP}$ from destruction debris on a tamped earth floor in Area B-1, Phase 10) has exactly the same age as the short-lived sample of olive pits (GrA-9624, $2930 \pm 50 \mathrm{BP}$ ). The other charcoal dates are older by, respectively, 30, 35, 50, 55, 60, 65, 70, and 90 midpoint yr BP. 
If the proposed young chronology by Finkelstein (1999) for Stratum V of 1000-900 BCE were correct, one must expect that at least some of the charcoal dates would come close to a calibrated date of 1000-900 BCE, as not all wood can be much older all the time. However, all charcoal dates from Dan Stratum V, as well as the short-lived date on olive pits, are much older than the period 1000900 BCE. Therefore, we reject the Finkelstein Low Chronology date for Tel Dan Stratum V.

\section{Megiddo Stratum VIA $=\mathrm{K} / 4$}

Finkelstein (1999) correlates Tel Dan Stratum V with Megiddo Stratum VIA. Therefore, if this archaeological correlation is correct, and if our ${ }^{14} \mathrm{C}$ dates for Tel Dan V are correct (considering an old-wood factor for charcoal in the range of $0-90 \mathrm{yr} \mathrm{BP}$ ), and if interlaboratory dating variations are small to negligible, then it should be expected that short-lived ${ }^{14} \mathrm{C}$ dates of Megiddo VIA are more or less similar to our Dan V dates.

A large number of ${ }^{14} \mathrm{C}$ dates of Iron Age strata from many sites in Israel were published by Sharon et al. (2007). Megiddo Stratum K/4, equated with Stratum VIA by Finkelstein et al. (2008) and also by Sharon et al. (2007), is represented in the above investigation with an impressive number of 21 dates (Sharon et al. 2007). We evaluated these dates and there are large differences between them, ranging from $3045 \pm 40 \mathrm{BP}$ (Rehovot AMS 3939.5) to $2735 \pm 40 \mathrm{BP}$ (Rehovot AMS 3943.3). However, these differences are usually not random, but are clearly related to the archaeological context of the various samples. Three groups of dates can be distinguished in relation to specific areas and/ or loci within Megiddo Stratum K/4 = VIA:

1. $2900+$ BP dates: archaeological contexts $00 / \mathrm{K} / 034,00 / \mathrm{K} / 008$, and $98 / \mathrm{K} / 032$ (Table 2).

2. $2800+$ BP dates: archaeological contexts $98 / \mathrm{K} / 043$ and $98 / \mathrm{K} / 031$ (Table 3 ).

3. $2700+$ BP dates: archaeological contexts $98 / \mathrm{K} / 036$ and $98 / \mathrm{K} / 037$ (Table 4 ).

Comparing the Megiddo Stratum VIA group of 2900+ BP dates (Table 2) with our Tel Dan Stratum $\mathrm{V}$ dates, it is clear that both are very similar indeed. Therefore, it can be concluded on the basis of chronostratigraphy that Tel Dan Stratum V and Megiddo Stratum VIA contexts 00/K/034, 00/K/ 008 , and $98 / \mathrm{K} / 032$ have the same age. The calibrated ranges (Table 2 and 1) are similar or slightly older than the conventional archaeological ages, as given by the Megiddo Chicago expedition, 1150-1100 BCE (Shiloh 1993) and by Biran (1994), 1200-1050 BCE. However, the 00/K/034, 00/ $\mathrm{K} / 008$, and $98 / \mathrm{K} / 032$ contexts of Megiddo VIA are much older than the Low Chronology dating of Finkelstein (1999).

The internal consistency of the Megiddo K/4 (=VIA) contexts 00/K/034, 00/K/008, and 98/K/032 ${ }^{14} \mathrm{C}$ dates is very good, as most overlap within 1 or $2 \sigma$. There is only 1 date that is somewhat younger (3944a Tucson AMS) than the others in this series of $8{ }^{14} \mathrm{C}$ results for the 3 archaeological contexts. It is clear that the ${ }^{14} \mathrm{C}$ results for contexts $98 / \mathrm{K} / 043$ and $98 / \mathrm{K} / 031$ (Table 3 ) and for contexts $98 / \mathrm{K} / 036$ and 98/K/037 (Table 4) each have their own time zone, except for 2 outliers in each group, being much older and closer to the dates in Table 2 . The ${ }^{14} \mathrm{C}$ dates of contexts $98 / \mathrm{K} / 043$ and 98/K/031 (Table 3) are very similar, except for the 1 outlier, and overlap within $1 \sigma$. The calibrated ranges overlap with Yadin's chronology (Shiloh 1993), having the same upper age of $\sim 1050$ BCE or slightly older but having a younger lower limit of $\sim 930 \mathrm{BCE}$. The ${ }^{14} \mathrm{C}$ dates also overlap with the Low Chronology (1000-900 BCE) of Finkelstein (1999), though being somewhat older.

Evaluating the consistent ${ }^{14} \mathrm{C}$ differences between the 3 different context groups of Stratum K/4 (VIA) - as shown in Tables 2, 3, and 4-it is clear that an overall average date for the 21 dates of this stratum would be a distortion of reality. What is wrong here, ${ }^{14} \mathrm{C}$ dating or archaeological stratigraphy? 
Table 2 Megiddo Stratum K/4 (=VIA) contexts 00/K/034, 00/K/008, and 98/K/032 ${ }^{14} \mathrm{C}$ dates (Sharon et al. 2007) in comparison with 3 archaeological age assessments for Stratum VIA: the Chicago Expedition, Yadin's Expedition (Shiloh 1993), and by Finkelstein's (1999) Low Chronology.

\begin{tabular}{|c|c|c|c|c|c|c|}
\hline $\begin{array}{l}\text { Arch. context } \\
\text { of Megiddo } \\
\text { Stratum K/4 } \\
\text { (=VIA) and } \\
\text { material }\end{array}$ & $\begin{array}{l}\text { Sample nr \& } \\
{ }^{14} \mathrm{C} \text { analysis }\end{array}$ & $\begin{array}{l}{ }^{14} \mathrm{C} \text { date } \\
(1 \sigma) \\
\text { yr BP }\end{array}$ & $\begin{array}{l}\text { Calibrated } \\
\text { date }^{\mathrm{a}}(1 \sigma) \\
\text { BCE }\end{array}$ & $\begin{array}{l}\text { Chicago } \\
\text { Expedition } \\
\text { chronology } \\
\text { VIB-VIA } \\
(\mathrm{BCE}) \\
\end{array}$ & $\begin{array}{l}\text { Yadin's } \\
\text { Expedition } \\
\text { chronology } \\
\text { VIA } \\
(\mathrm{BCE}) \\
\end{array}$ & $\begin{array}{l}\text { Finkelstein } \\
\text { Low } \\
\text { Chronology } \\
\text { VIA } \\
\text { (BCE) } \\
\end{array}$ \\
\hline $\begin{array}{l}00 / \mathrm{K} / 034 \\
\text { seeds }\end{array}$ & $\begin{array}{l}\text { 3946a } \\
\text { Tucson AMS }\end{array}$ & $2910 \pm 35$ & 1190-1026 & $1150-1100$ & $1050-1000$ & $1000-900$ \\
\hline $\begin{array}{l}00 / \mathrm{K} / 034 \\
\text { seeds }\end{array}$ & $\begin{array}{l}\text { 3946aa } \\
\text { Tucson AMS }\end{array}$ & $2904 \pm 40$ & 1188-1014 & $1150-1100$ & $1050-1000$ & $1000-900$ \\
\hline $\begin{array}{l}00 / \mathrm{K} / 008 \\
\text { seeds }\end{array}$ & $\begin{array}{l}\text { 3945a } \\
\text { Tucson AMS }\end{array}$ & $2958 \pm 40$ & $1260-1122$ & $1150-1100$ & $1050-1000$ & $1000-900$ \\
\hline $\begin{array}{l}00 / \mathrm{K} / 008 \\
\text { seeds }\end{array}$ & $\begin{array}{l}\text { 3945aa } \\
\text { Tucson AMS }\end{array}$ & $2912 \pm 45$ & $1192-1021$ & $1150-1100$ & $1050-1000$ & $1000-900$ \\
\hline $\begin{array}{l}98 / \mathrm{K} / 032 \\
\text { seeds }\end{array}$ & $\begin{array}{l}3944.3 \\
\text { Rehovot AMS }\end{array}$ & $2975 \pm 60$ & 1310-1116 & $1150-1100$ & $1050-1000$ & $1000-900$ \\
\hline $\begin{array}{l}98 / \mathrm{K} / 032 \\
\text { seeds }\end{array}$ & $\begin{array}{l}3944.4 \\
\text { Rehovot AMS }\end{array}$ & $2980 \pm 50$ & $1294-1127$ & $1150-1100$ & $1050-1000$ & $1000-900$ \\
\hline $\begin{array}{l}98 / \mathrm{K} / 032 \\
\text { seeds }\end{array}$ & $\begin{array}{l}3944.5 \\
\text { Rehovot AMS }\end{array}$ & $2905 \pm 60$ & $1208-1008$ & $1150-1100$ & $1050-1000$ & 1000-900 \\
\hline $\begin{array}{l}98 / \mathrm{K} / 032 \\
\text { seeds }\end{array}$ & $\begin{array}{l}\text { 3944a } \\
\text { Tucson AMS }\end{array}$ & $2864 \pm 40$ & 1113-977 & $1150-1100$ & $1050-1000$ & $1000-900$ \\
\hline
\end{tabular}

Table 3 Megiddo Stratum K/4 (=VIA) contexts 98/K/043 and 98/K/031 ${ }^{14} \mathrm{C}$ dates (Sharon et al. 2007) in comparison with 3 archaeological age assessments for Stratum VIA: the Chicago Expedition, Yadin's Expedition (Shiloh 1993), and by Finkelstein's (1999) Low Chronology.

\begin{tabular}{|c|c|c|c|c|c|c|}
\hline $\begin{array}{l}\text { Arch. context } \\
\text { of Megiddo } \\
\text { Stratum K/4 } \\
\text { (=VIA) and } \\
\text { material }\end{array}$ & $\begin{array}{l}\text { Sample nr \& } \\
{ }^{14} \mathrm{C} \text { analysis }\end{array}$ & $\begin{array}{l}{ }^{14} \mathrm{C} \text { date } \\
(1 \sigma) \\
\text { yr BP }\end{array}$ & $\begin{array}{l}\text { Calibrated } \\
\text { date }^{\mathrm{a}}(1 \sigma) \\
\mathrm{BCE}\end{array}$ & $\begin{array}{l}\text { Chicago } \\
\text { Expedition } \\
\text { chronology } \\
\text { VIB-VIA } \\
(\mathrm{BCE})\end{array}$ & $\begin{array}{l}\text { Yadin's } \\
\text { Expedition } \\
\text { chronology } \\
\text { VIA } \\
(\mathrm{BCE}) \\
\end{array}$ & $\begin{array}{l}\text { Finkelstein } \\
\text { Low } \\
\text { Chronology } \\
\text { VIA } \\
\text { (BCE) }\end{array}$ \\
\hline & $\begin{array}{l}3942.3 \\
\text { Rehovot AMS }\end{array}$ & $2845 \pm 37$ & $1051-930$ & $1150-1100$ & $1050-1000$ & $1000-900$ \\
\hline $\begin{array}{l}98 / \mathrm{K} / 043 \\
\text { olive pits }\end{array}$ & $\begin{array}{l}42.4 \\
\text { ehovot AMS }\end{array}$ & $2832 \pm 43$ & $1041-924$ & $1150-1100$ & $1050-1000$ & $1000-900$ \\
\hline $\begin{array}{l}98 / \mathrm{K} / 043 \\
\text { olive pits }\end{array}$ & $\begin{array}{l}3942.5 \\
\text { Rehovot AMS }\end{array}$ & $2856 \pm 42$ & $1111-938$ & $1150-1100$ & $1050-1000$ & $1000-900$ \\
\hline $\begin{array}{l}98 / \mathrm{K} / 043 \\
\text { olive pits }\end{array}$ & $\begin{array}{l}3942.6 \\
\text { Rehovot AMS }\end{array}$ & $2849 \pm 36$ & $1045-930$ & $1150-1100$ & $1050-1000$ & $1000-900$ \\
\hline $\begin{array}{l}98 / \mathrm{K} / 031 \\
\text { seeds }\end{array}$ & $\begin{array}{l}3943.3 \\
\text { Rehovot AMS }\end{array}$ & $3045 \pm 40$ & $1384-1264$ & $1150-1100$ & $1050-1000$ & $1000-900$ \\
\hline $\begin{array}{l}98 / \mathrm{K} / 031 \\
\text { seeds }\end{array}$ & $\begin{array}{l}3943.4 \\
\text { Rehovot AMS }\end{array}$ & $2860 \pm 40$ & $1112-943$ & $1150-1100$ & $1050-1000$ & $1000-900$ \\
\hline $\begin{array}{l}\text { 98/K/031 } \\
\text { seeds }\end{array}$ & $\begin{array}{l}3943.5 \\
\text { Rehovot AMS }\end{array}$ & $2845 \pm 40$ & $1052-928$ & $1150-1100$ & $1050-1000$ & $1000-900$ \\
\hline
\end{tabular}


Table 4 Megiddo Stratum K/4 (=VIA) contexts 98/K/036 and 98/K/037 ${ }^{14} \mathrm{C}$ dates (Sharon et al. 2007) in comparison with 3 archaeological age assessments for Stratum VIA: the Chicago Expedition, Yadin's Expedition (Shiloh 1993), and by Finkelstein's (1999) Low Chronology.

\begin{tabular}{|c|c|c|c|c|c|c|}
\hline $\begin{array}{l}\text { Arch. context } \\
\text { of Megiddo } \\
\text { Stratum K/4 } \\
\text { (=VIA) and } \\
\text { material }\end{array}$ & $\begin{array}{l}\text { Sample nr \& } \\
{ }^{14} \mathrm{C} \text { analysis }\end{array}$ & $\begin{array}{l}{ }^{14} \mathrm{C} \text { date } \\
(1 \sigma) \\
\mathrm{yr} \mathrm{BP}\end{array}$ & $\begin{array}{l}\text { Calibrated } \\
\text { date }^{(1 \sigma)} \\
\text { BCE }\end{array}$ & $\begin{array}{l}\text { Chicago } \\
\text { Expedition } \\
\text { chronology } \\
\text { VIB-VIA } \\
\text { (BCE) }\end{array}$ & $\begin{array}{l}\text { Yadin's } \\
\text { Expedition } \\
\text { chronology } \\
\text { VIA } \\
\text { (BCE) }\end{array}$ & $\begin{array}{l}\text { Finkelstein } \\
\text { Low } \\
\text { Chronology } \\
\text { VIA } \\
\text { (BCE) }\end{array}$ \\
\hline $\begin{array}{l}98 / \mathrm{K} / 036 \\
\text { seeds }\end{array}$ & $\begin{array}{l}3939.3 \\
\text { Rehovot AMS }\end{array}$ & $2910 \pm 45$ & $1191-1018$ & $1150-1100$ & $1050-1000$ & $1000-900$ \\
\hline $\begin{array}{l}98 / \mathrm{K} / 036 \\
\text { seeds }\end{array}$ & $\begin{array}{l}3939.4 \\
\text { Rehovot AMS }\end{array}$ & $2790 \pm 40$ & $1000-900$ & $1150-1100$ & $1050-1000$ & $1000-900$ \\
\hline $\begin{array}{l}98 / \mathrm{K} / 036 \\
\text { seeds }\end{array}$ & $\begin{array}{l}3939.5 \\
\text { Rehovot AMS }\end{array}$ & $2735 \pm 40$ & $911-831$ & $1150-1100$ & $1050-1000$ & $1000-900$ \\
\hline $\begin{array}{l}98 / \mathrm{K} / 037 \\
\text { seeds }\end{array}$ & $\begin{array}{l}3940.3 \\
\text { Rehovot AMS }\end{array}$ & $2760 \pm 40$ & 969-840 & $1150-1100$ & $1050-1000$ & $1000-900$ \\
\hline $\begin{array}{l}98 / \mathrm{K} / 037 \\
\text { seeds }\end{array}$ & $\begin{array}{l}3940.4 \\
\text { Rehovot AMS }\end{array}$ & $2770 \pm 40$ & $974-843$ & $1150-1100$ & $1050-1000$ & $1000-900$ \\
\hline $\begin{array}{l}98 / \mathrm{K} / 037 \\
\text { seeds }\end{array}$ & $\begin{array}{l}3940.5 \\
\text { Rehovot AMS }\end{array}$ & $2775 \pm 55$ & $994-843$ & $1150-1100$ & $1050-1000$ & 1000-900 \\
\hline
\end{tabular}

a Dates calibrated with OxCal v 3.10 (Bronk Ramsey 2001, 2005) using the IntCal04 calibration curve (Reimer et al. 2004).

It seems to us that there is a stratigraphic archaeological excavation problem at Megiddo. Fantalkin et al. (2011) quote from Ilan (1999:28) to underline their judgment of a chaotic stratigraphy at Tel Dan: “...stratigraphic resolution is not always sharp as might be expected." However, the ${ }^{14} \mathrm{C}$ dates for Stratum V at Tel Dan, derived from different areas and loci, are consistent, differing from each other by no more than 90 midpoint yr BP, even though many charcoal dates are involved! But Tel Megiddo Stratum K/4 (=VIA) has differences between ${ }^{14} \mathrm{C}$ dates of up to 310 midpoint yr BP, even though the 21 Megiddo dates are all derived from short-lived samples (seeds or olive pits)!

Since these large differences between the $21{ }^{14} \mathrm{C}$ dates by Sharon et al. (2007) for Megiddo Stratum $\mathrm{K} / 4$ (=VIA) do not occur randomly, but can be put together into 3 distinct age groups, which are internally consistent, our conclusion is $n o t{ }^{14} \mathrm{C}$ dating but the stratigraphy in Area $\mathrm{K}$ of Tel Megiddo is problematic. It is impossible that contexts $00 / \mathrm{K} / 034,00 / \mathrm{K} / 008,98 / \mathrm{K} / 032$ (Table 2), 98/K/043, 98/ K/031 (Table 3), and 98/K/036, 98/K/037 (Table 4) all belong to 1 stratum, K/4 (VIA), which lasted from about 1200 to $840 \mathrm{BCE}$, according to the above ${ }^{14} \mathrm{C}$ dates. Evidently, various archaeological strata in Area $\mathrm{K}$ of Tel Megiddo from totally different centuries in the Iron Age have been put together by the excavators as 1 stratum, i.e. $\mathrm{K} / 4$.

Our conclusions are that ${ }^{14} \mathrm{C}$ dating may give a more refined stratigraphic resolution than is possible with conventional archaeological excavation techniques. Moreover, Megiddo Stratum K/4 (VIA) contexts $00 / \mathrm{K} / 034,00 / \mathrm{K} / 008$, and $98 / \mathrm{K} / 032$ (Table 2) belong to the same age group as Tel Dan Stratum V, in remarkable agreement with the archaeological age assessment by Biran (1994), 12001050 BCE, but incompatible with the Low Chronology, 1000-900 BCE, of Finkelstein (1999).

\section{Horvat Haluqim}

Concerning Horvat Haluqim, Fantalkin et al. (2011:180) make an opening statement that is styled as a fait accompli: "Unlike floors in a stratified site, earth behind built terraces cannot provide a secure stratigraphic sequence." The authors do not differentiate between terraces on hill slopes in a Medi- 
terranean climate and cross-channel terraces in desert valleys (wadis). Their statement may indeed apply to terraces built on slopes in the hills and mountains of Judea, Samaria, and Galilee, where earth was apparently moved in place artificially with the building of stone terrace walls to make horizontal soil platforms suited for rainfed or irrigation agriculture on steep to moderate slopes (Edelstein and Kislev 1981; Stager 1982; Dar 1986; Faust 2000). However, the above statement is not valid for cross-channel terraces in valleys (wadis) built for runoff farming in the Negev and other arid zones in the world (Bruins et al. 1986; Bruins 1990, 2003, 2007; Bruins and van der Plicht 2004, 2005, 2007). A secure stratigraphic sedimentary sequence, in which human activities may be recorded, will develop in such terraced wadi systems (Bruins 2003), as explained below.

Unlike agricultural terraces on hill slopes, the soil surface in valleys is by nature rather horizontal and does usually not require artificial human-made earth movements to create agricultural fields. Moreover, runoff generation and sediment transport is limited in semi-arid and subhumid areas with a Mediterranean vegetation, but in the arid zone runoff overland flow with transport of fine sediment is common (Lavee et al. 1998). Thus, the dry stone walls built in suitable small wadis to arrest the flow of runoff water to enable farming in the desert (Evenari et al. 1982) acted also as barriers that induced the accumulation of fine sediment on the original soil surface. Environmental and geological processes therefore caused the gradual formation of a stratigraphic sedimentary sequence in wadi terraces following the building of cross-channel stone walls. This sedimentary sequence also recorded human activities at Horvat Haluqim, such as soil manuring (Bruins and van der Plicht 2004; Bruins 2005, 2007).

New layers of stones had to be added to the terrace walls in the course of time in order to keep the walls above the upward growing soil surface, due to continuous sediment accumulation. Otherwise, runoff water would not be retained in sufficient quantity. Therefore, the very fact that certain terrace walls reached a much higher level than others, without any specific geomorphological reason, is proof that such terraces were used over longer time periods, as is the case for Terrace 12 in the eastern wadi of Horvat Haluqim, involving various archaeological periods.

Such accumulative geoarchaeological environments in the Negev Highlands contain secure stratigraphic sequences, which are unique. Unlike building remains that usually cover more limited time intervals, a wadi terrace has the potential of recording a longer and more continuous period of integrated environmental and human history from the time the lowest stone course of a terrace wall was built, which started the runoff sediment accumulation recording mechanism.

Terrace 12 in the eastern wadi at Horvat Haluqim apparently has the longest record of terrace usage anywhere in the world, as far as we know. It is the oldest runoff farming terrace so far discovered in the Negev. The lowermost dark-gray anthropogenic soil, at the base level of the terrace wall, showing evidence of soil manuring, both macroscopically and in terms of micromorphology, dates to the early 5th millennium BCE, time parallel with both the Timnian (Rosen 2006) and Besorian (Gilead 2007), at the Neolithic-Chalcolithic time transition. The middle-upper dark-gray anthropogenic soil, also featuring purposeful additions to the soil (manuring) to improve soil fertility (Bruins and van der Plicht 2004; Bruins 2005, 2007), dates to the Bronze and Iron ages. The highest levels of Terrace 12 (Area 3) include a date in the subsoil of the Early Islamic period.

Fantalkin et al. (2011:180) continue their criticism with the following sentence: "Moreover, they lack ceramic assemblages and hence cannot be correlated with nearby habitation sites." We do not agree that only ceramics can provide a basis for dating and correlation. What about ${ }^{14} \mathrm{C}$ dating or optically stimulated luminescence (TSL) dating (Avni et al. 2009) of wadi terrace layers? First of all, ceramic sherds, usually Negbite but also other types, as well as worked flint, do occur in the terrace 
layers of Terrace 12. Such an appearance of limited amounts of scattered ceramic and flint material in a soil context (Wilkinson 1989) - characterized at Horvat Haluqim by an unusual dark-gray (more ash-like) color and charred organic material from the microscopic level (few microns) to the macroscopic level, as well as the presence of bone remnants, including tiny pieces of burned bones $(1 \mathrm{~mm})$ at the microscopic level - is typical for manuring practices, using home refuse and other organic sources to increase soil fertility in the context of runoff agriculture.

Unfortunately, the factual time resolution of ceramic dating in the Iron and Bronze ages in the Levant in general and in the Negev in particular may be limited in resolution and precision. Negbite ware often dominates in the south (Haiman 1994), but this type of ceramics cannot be used for dating. Even the beginning and end of diagnostic types of pottery is not always clear in absolute time. The detailed ${ }^{14} \mathrm{C}$ investigation at Tel Rehov showed that the Iron IIA ceramic assemblages of the 10th and 9th century BCE are rather similar (Bruins et al. 2003a,b; Mazar et al. 2005).

Terrace 12 includes many charred organic materials, as well as bones, described above, which can be used for ${ }^{14} \mathrm{C}$ dating. Indeed, ${ }^{14} \mathrm{C}$ dating rather than pottery should be the principal dating approach to correlate strata in terraces with strata in buildings at various spatial dimensions: within a terrace, within a building, between various elements within a site, between sites, and across larger geographic units. This is the great advantage of ${ }^{14} \mathrm{C}$ dating: to be able to assort and synchronize archaeological, geological, and even historical contexts (Bruins and van der Plicht 2003; Bronk Ramsey et al. 2010, Bruins 2010).

Fantalkin et al. (2011:180) state:

"In order to ${ }^{14} \mathrm{C}$ date the Negev Highlands sites, one needs to retrieve short-lived samples from safe contexts on their floors. The value of such an endeavor has recently been shown in careful stratigraphic excavations carried out by Shahack-Gross and Finkelstein (2008) in two nearby sites: Atar Haroa and Nahal Boqer..."

Indeed, the Negev Highland sites are rural sites par excellence. We agree that the geoarchaeological approach by Shahack-Gross is an important new line of research in the region to obtain new data in terms of rural archaeology, based on the expertise developed in these fields by the Kimmel Center for Archaeological Science at the Weizmann Institute. However, at the rural site of Atar Haroa, Shahack-Gross and Finkelstein (2008) only investigated parts of the "oval compound," as they call it, i.e. the "oval fortress" in the terminology of Cohen and Cohen-Amin (2004). We do not agree with some of the conclusions by Shahack-Gross and Finkelstein (2008), which seem to have been skewed by predetermined viewpoints, according to theories developed by Finkelstein (1984, 1986, 1995, 1996). The detailed descriptions of micromorphology, dung, and other geoarchaeological components in the article by Shahack-Gross and Finkelstein (2008) are impressive, but stratigraphic drawings or charts of each of the excavated rooms and central courtyards are missing. Though photographs are provided, stratigraphic detail is not graphically indicated to assist the reader where to place the various samples that were investigated. What are the boundaries and respective thicknesses of the various layers in each locus, including the position of the floors that were recognized, as well as an indication of the positions from where the various samples were taken that are described in the article in great detail? What layer here is considered to be the Iron Age IIA stratum and on what basis? What is the upper boundary of this stratum and what is its lower boundary? Also, the position of the ${ }^{14} \mathrm{C}$ dates (Boaretto et al. 2010) is not indicated in the stratigraphy. For example, what is the precise position and depth below the surface of the ${ }^{14} \mathrm{C}$-dated date-palm pits, found in 2 casemate rooms, as one has a 2- $\sigma$ calibrated age range of 1120-890 BCE and the other 910-790 $\mathrm{BCE}$ ? Do both dates belong to the Iron Age IIA stratum? It seems we have here 2 separate time periods, and the oldest date could well belong to Iron I. 
Based on their sophisticated geoarchaeological investigations, Shahack-Gross and Finkelstein (2008:980) come to the conclusion that the "oval compound" (or "oval fortress," according to Cohen and Cohen-Amin 2004) at Atar Haroa was inhabited by "caprine herding pastoralists" who "did not practice seasonal dry-farming." We do not agree with these far-reaching conclusions. First, "dry-farming" is not the correct wording, because farming is not possible in the Negev Highlands without the harvesting and use of runoff water. Secondly, the authors base their conclusion only on excavations in the "oval compound," i.e. a building with casemate rooms. Farming is obviously not done in buildings. Whatever the merits and interpretations regarding the geoarchaeological findings about pastoralism at this spot, it cannot prove that agriculture was not practiced at Atar Haroa during the Iron Age. In fact, agricultural wadi terraces for runoff farming exist in the valley below the "oval compound" at Atar Haroa, but these were not investigated by Shahack-Gross and Finkelstein.

Bruins pioneered and developed novel excavation techniques in ancient agricultural terraces at Horvat Haluqim, based on soil stratigraphy, soil properties, micromorphology, and ${ }^{14} \mathrm{C}$ dating. Terrace 12 , designed for runoff farming in the eastern wadi, contains layers characterized by remains of ancient soil manuring, dated by ${ }^{14} \mathrm{C}$ to the Iron Age, including the 12th, 11th, and 10th centuries $\mathrm{BCE}$, as well as older layers, and also younger layers! The same archaeo-soil excavation technique is now also being applied to various building remains at Horvat Haluqim with cooperation of Mordechai Haiman (Israel Antiquities Authority). The soils in the building remains are carefully examined centimeter by centimeter to obtain stratigraphic detail of all tiny layers, including living floors.

Two silos were discovered during the excavations conducted by Bruins and Haiman next to Terrace 12 in 2009. A flint sickle blade with gloss was discovered in one of the silos, indicating it was actually used for the harvesting of cereal grains in the eastern wadi of Horvat Haluqim. This sickle blade is diagnostic for the Iron Age or Bronze Age, according to Steve Rosen (1997; personal communication, 2010). Of course, this is only preliminary information, as investigations are still continuing and these new findings will be published later in detail.

In addition, Bruins and Haiman also carry out excavations in other buildings at Horvat Haluqim, including the Oval Fortress. Here, in the central courtyard, we have also found a sickle blade with gloss, which is diagnostically typical for the Iron Age, according to Rosen (1997; personal communication, 2010). The Oval Fortress at Horvat Haluqim is situated also along the eastern wadi. We also have ${ }^{14} \mathrm{C}$ dates from the Oval Fortress, to be published later, that are similar to those from some of the Iron Age layers in the agricultural wadi Terrace 12. Therefore, all the above new findings at Horvat Haluqim strengthen us in our opinion - contra Shahack-Gross and Finkelstein (2008) - that the Iron Age inhabitants of the Negev Highlands practiced runoff farming, in addition to pastoralism.

Finally, Fantalkin et al. (2011:181) question the validity of our ${ }^{14} \mathrm{C}$ dates by stating that these are merely based on "the charred wood found in the nearby agricultural terrace." Well, as already explained above, the nearby agricultural terrace has a unique stratigraphic record with very consistent ${ }^{14} \mathrm{C}$ dates, in terms of depth-age relationships. Labeling our dated organic material as "charred wood" is not correct. First, there are hardly any trees that grow naturally in the Negev Highlands. Secondly, some of the $\delta^{13} \mathrm{C}$ values of the published dates (Bruins and van der Plicht 2005, 2007) are $\mathrm{C}_{4}$ plants, -11.97 and $-11.16 \%$, being shrubs or annual plants, which may both be regarded as short lived. Thirdly, all the other $\delta^{13} \mathrm{C}$ values of charred organic matter in Bruins and van der Plicht (2007: $491)$ are in the range of -21.03 to $-23.71 \%$. The $\delta^{13} \mathrm{C}$ values of charred wood are usually lower (more negative), as can be seen from the real wood charcoal dates from Tel Dan (Bruins et al. 2005a: Table 19.1), in which 14 samples range from -24.50 to $-25.56 \%$, including Pistacia atlantica, Quercus boissieri, and Quercus ithaburensis. Only 1 wood sample from Tel Dan was less negative, 
Olea europea, $-23.39 \%$. Fourth, also bones of sheep/goats have been dated at Horvat Haluqim, which are short lived. Fifth, most charred organic samples from Terrace 12 do not have a macroscopic constitution that resembles a wood structure. Sixth, it may be possible that some of the charred organic matter in Terrace 12 is derived from dung that was used as domestic fuel, but this needs to be investigated. Seventh, even if some of the samples are derived from wood, the results should not be regarded a priori as worthless. Indeed, the true wood charcoal dates from Tel Dan Stratum $\mathrm{V}$ are more homogeneous and consistent than the charred seed samples attributed to Megiddo Stratum VIA (K/4), as described and evaluated above.

\section{Tell el-Qudeirat}

Three of the 4 mentioned organic samples were taken by Bruins at Tell el-Qudeirat during the excavations in December 1981. We agree with the comments of Fantalkin et al. (2011) that the oldest sample (2930 $\pm 30 \mathrm{BP}, \mathrm{GrN}-12330$ ), having a 1- $\sigma$ calibrated range of $1208-1055 \mathrm{BCE}$, is most relevant in the Iron Age chronology debate. This sample was collected together with the chief excavator, Rudolph Cohen, who considered this lowest black layer in Square K/6-7 a destruction layer synchronous with the Oval Fortress, according to Bruins' field notes.

Fantalkin et al. (2011) designate this sample "long lived," which is by no means certain. That is their conjecture. The sample was derived from an amorphous black layer without obvious charred wood components. The $\delta^{13} \mathrm{C}$ value of this sample is $-22.53 \%$, which is less negative than a number of wood species mentioned above.

For comparison, the uppermost black destruction layer of this same western baulk profile in Square $\mathrm{K} / 6-7$, considered by Rudolph Cohen synchronous with the destruction of the Upper Fortress, yielded a ${ }^{14} \mathrm{C}$ date $(2535 \pm 50 \mathrm{BP}, \mathrm{GrN}-12329)$, which is only 20 midpoint yr BP older than charred cereal grains (2515 $\pm 15 \mathrm{BP}, \mathrm{GrN}-15551)$ found in a jar in a destruction layer of the Upper Fortress (Bruins and van der Plicht 2005). The uppermost black destruction layer was also characterized by amorphous charred organic material without distinct charred wood constituents. The $\delta^{13} \mathrm{C}$ value of the amorphous sample is $-22.89 \%$, quite similar to the lowermost black destruction layer.

The black and white picture presented by Fantalkin et al. (2011) - either seeds or wood - is misleading. If a charred organic sample is not composed of charred seeds, it does not imply it is charred wood, nor is it certain that the sample is long lived, an argument used against us by Fantalkin et al. (2011) throughout their rejoinder. There are so many other types of plant material, such as annuals, dung, and shrubs that are short lived or reasonably short lived, which can be the constituents of an amorphous black layer. We strongly urge that all such black layers in stratigraphic sections be used for ${ }^{14} \mathrm{C}$ dating in order to have detailed coverage of chronostratigraphic resolution. If only seeds can be used in ${ }^{14} \mathrm{C}$ dating, archaeology will lose a lot of very valuable stratigraphic and chronological information.

We agree with Fantalkin et al. (2011) that the lowermost black layer in Square K/6-7 was probably not situated within the Oval Fortress (Substratum 4b), in view of the descriptions by the excavators (Shor and Bernick-Greenberg 2007:67). However, we do not agree that our date (2930 \pm 30 BP, GrN-12330) should be assigned stratigraphically to the pre-fortress settlement, which is defined as Substratum 4c. The reason is simple: Substratum $4 \mathrm{c}$ is not mentioned as existing in Area $\mathrm{C}$, in which Square K/6-7 is located (Cohen and Bernick-Greenberg 2007: Plan 3, plan of Substrata 4c and 4b). Bernick-Greenberg (2007:142) states concerning the pre-fortress period, Substratum 4c: "Floors underlying the walls of the Oval Fortress were uncovered only in the southern part of Area E and in a few places below the settlement layer (Areas B, F)." Therefore, we consider it stratigraphically 
most likely that the lowermost black layer in Area C, Square K6/7, from where our ${ }^{14} \mathrm{C}$ date is derived $(2930 \pm 30 \mathrm{BP}, \mathrm{GrN}-12330,1208-1055 \mathrm{cal} \mathrm{BCE}, 1 \sigma)$, relates to the unfortified settlement just west of the Oval Fortress, being contemporaneous (Substratum 4b) with the Oval Fortress (Cohen and Bernick-Greenberg 2007:8; Shor and Bernick-Greenberg 2007:70; Bernick-Greenberg 2007:142).

The obvious implication of our assessment is that the Oval Fortress at Tell el-Qudeirat already existed in Iron I. Although this response article is not the appropriate context to present new data in detail, which will be done in another publication, also in relation to Singer-Avitz (2008) and Finkelstein (2010), we include here a few reasons for our preliminary conclusions:

1. The Oval Fortress (in the terminology of Cohen [1976]) at Horvat Haluqim is quite similar in shape and size as the Oval Fortress at Tell el-Qudeirat. We now have a number of ${ }^{14} \mathrm{C}$ dates from the Horvat Haluqim Oval Fortress that include the Iron Age I time period. More samples will be dated in the near future.

2. The important new series of ${ }^{14} \mathrm{C}$ dates for the Oval Fortress or "oval compound" at Atar Haroa (Boaretto et al. 2010) also appear to include Iron Age I dates, particularly in the Low Chronology perspective of Finkelstein, in which Iron I continues to 900 BCE, though the site is classified in their publication only as Iron IIA.

3. It is agreed by the excavators of Tell el-Qudeirat that some of the pottery types found in the Stratum 4 Oval Fortress and the settlement alongside "are common in the Negev both in Iron I and Iron IIA" (Bernick-Greenberg 2007:142-3).

4. Midianite pottery was found at Tell el-Qudeirat (Bernick-Greenberg 2007:140-1) similar to the types excavated at Timna, where it was dated by the presence of accompanying Egyptian ceramics to the 13th-11th century BCE (Rothenberg 1972, 1988; Rothenberg and Glass 1981, 1983).

5. The above-mentioned findings of Iron I and Midianite pottery do not relate, according to the excavators, to the pre-fortress occupation of Substratum 4c. Concerning Substratum 4c, Bernick-Greenberg (2007:141) notes: "The material from this level is not diagnostic, it has not been illustrated and there is too little to date this substratum."

\section{Khirbet en-Nahas}

The opening statement by Fantalkin et al. (2011:181) concerning Khirbet en-Nahas leaves no doubt about their viewpoint: "This site ... cannot contribute to the Iron Age chronology debate." One of their reasons is that Khirbet en-Nahas is "not a stratified settlement." That argument sounds already familiar. It is clear, the same arguments are used in an attempt to simply erase any archaeological site that produces Iron Age ${ }^{14} \mathrm{C}$ dates that are older than expected from their concepts. We consider this a misleading statement, as any archaeological site, also a rural site, as well as a copper-producing industrial site, has a stratigraphy, which can be investigated with ${ }^{14} \mathrm{C}$ dating. See, for example, the detailed stratigraphic investigation by Levy et al. (2008) through an industrial copper slag mound of $6 \mathrm{~m}$ in depth, adjacent to a 4-room building in Area $\mathrm{M}$ at Khirbet en-Nahas. Architecture is only one of the human activities of the past and to think merely in terms of walls and stone floors is reductionism of the stratigraphic concept and the use of geographic space in ancient times.

Criticism of this overemphasis on architecture in Near Eastern archaeology was voiced in the 1960s by Franken and Franken-Battershill (1963:8-9):

"This group is typified by its adherence to the old Classical archaeologists who were working largely on stone built sites, perhaps only partly covered with earth. For them as for the Petrie followers, walls, paved 
floors and the like are all important. Objects found within a certain complex of walls are dated alike without a close regard for the earth filling of that complex ... Very often the writers of excavation reports state that various buildings could not with certainty be attributed to a stratum, and that many objects found outside buildings are of uncertain provenance. This shows that excavation outside buildings went on in the Petrie-fashion, without a proper analysis of the earth deposits."

The above authors list many sites, including Megiddo, which were excavated in this manner prior to the time of their writing in 1963.

Concerning Khirbet en-Nahas, in their response to similar criticism by Finkelstein (2005), the excavators, T Levy and M Najjar, elucidated the stratification of the site and noted: "there is a disturbing trend in Finkelstein's recent work to ignore data or simply force it into his model" (Levy and Najjar (2006:4).

Also, the charcoal dates of Khirbet en-Nahas were dismissed as worthless by Finkelstein (2005), then as well as in the current rejoinder (Fantalkin et al. 2011), although the outermost rings of tamarisk branches were used by Levy et al. (2005), as explained by Higham et al. (2005), which renders these charcoal dates as short lived.

Finally, a quotation from Levy and Najjar (2006:9) about the ${ }^{14} \mathrm{C}$ dating results from Khirbet enNahas (=KEN):

"The breakdown of the dates shows two peaks of copper production activities in the 12th-11th and 10th9th centuries BCE (Levy et al. 2004; 2005; Higham et al. 2005); and 2) There is no evidence for 8th through 6th century BCE metal production at KEN - the period traditionally associated with state formation in Edom (Bienkowski 2001; Porter 2004). In short, Finkelstein seems unwilling to acknowledge the new data from our excavations and analyses of Iron I-Iron Age IIA occupation in the Feinan district..."

\section{Tel Rehov}

Tel Rehov (Mazar 2003; Mazar et al. 2005) is a well-stratified site in terms of architecture with ${ }^{14} \mathrm{C}$ dates mainly based on seeds (Bruins et al. 2003a,b, 2005b, 2007; Mazar 2004; Mazar et al. 2005; van der Plicht and Bruins 2005; Mazar and Bronk Ramsey 2008, 2010). These results support in our opinion clearly a High Chronology or "Extended Conventional Chronology" (Mazar 2004), while Finkelstein and Piasetzky $(2003,2006,2008,2010)$ continue in their endeavors to try to force the results into a Low Chronology framework.

It is clear from the above references that much has already been written about the ${ }^{14} \mathrm{C}$ dates of $\mathrm{Tel}$ Rehov. We do not agree with the objections raised by Fantalkin et al. (2011) and the reasons have already been stated in the publications mentioned above. Moreover, in a recent article, Mazar and Bronk Ramsey (2010) objected to the inclusion of certain loci in the Bayesian models by Finkelstein and Piasetzky: "It is clear that they mistakenly include data from Tel Rehov Stratum V by mixing secure loci from this stratum with loci defined by the excavators as belonging to either Stratum V or Stratum IV" (Mazar and Bronk Ramsey 2010:1687).

We do not agree with the Bayesian models by Fantalkin et al. (2011) concerning Tel Rehov. The destruction time of Stratum V, for example, has to be younger in time than the preceding duration of Stratum V, requiring 2 phases. We prefer the Bayesian model published by Bruins et al. (2005b).

\section{THE CENTRAL AND WESTERN MEDITERRANEAN REGION}

There seems to be agreement between Fantalkin et al. (2011) and us that Levantine material from the early Iron IIA period onwards was recovered at Huelva in SW Spain on the Atlantic coast, marking 
there the transition from the Late Bronze Age to the Early Iron Age. Thus, a debate on the absolute chronology of Iron IIA in the southern Levant becomes relevant for the whole Mediterranean, since it is very unlikely that the Phoenicians traveled to the far West without occasionally stopping in between on a shore for exchange, freshwater, and food. A site like Torre Galli in Calabria (southern Italy) might have functioned as such a stopping place, as its tombs contain Levantine imports (Pacciarelli 1999:61-2, 101-2; Nijboer 2008:430-1; Sciacca, forthcoming). Moreover, it is the only site in Italy with a significant quantity of iron from the earliest phases of the Iron Age onwards. Its iron daggers/swords are often embellished with ivory, another Levantine import. The catalogue of the necropolis contains 205 Early Iron Age tombs that could be assigned to either Torre Galli phase IA ( 89 tombs) or phase IB (116 tombs), roughly dated here from 950 to 900 and from 900 to 850 BC (Pacciarelli 1999:62-5). From these 205 tombs, 56 contained 1 or more iron artifacts, i.e. $25 \%$ of the Early Iron Age tombs at Torre Galli. Therefore, sites like Huelva and Torre Galli, both associated with the introduction of iron as a novel material, record the early exploits of the Phoenicians in the western Mediterranean prior to the arrival of the Euboeans and other Greek groups, who apparently entered the stage from $\sim 800 \mathrm{BCE}$ onwards.

Notwithstanding this positive note on perceptible concord between Fantalkin et al. (2011) and us, they distort our ${ }^{14} \mathrm{C}$ dates for the central and western Mediterranean in many ways. Moreover, after reading their text, it is clear that their knowledge of the archaeological record of Italy and the western Mediterranean is at best limited.

\section{Italy}

The critique by Fantalkin et al. (2011) on our ${ }^{14} \mathrm{C}$ data set from the central and western Mediterranean is partially based on the nature of the archaeological contexts that we have tested. These are not stratified settlement layers as those examined in Israel (cf. Sharon et al. 2007). Such a stratigraphic setup hardly exists in Italy, or for that matter in many other regions, as most Iron Age settlements were cut in bedrock and do not usually have a continuous stratigraphy covering the period 1200750 BCE. Moreover, many smaller settlements in Italy were deserted during this period in order to inhabit more extensive plateaus that could house a larger population. A recently explored, waterlogged site near Naples, called Poggiomarino, with a duration from the Middle Bronze Age until $\sim 600 \mathrm{BC}$, might provide us in the future with a detailed stratigraphic and chronological reading, but these data are not yet available (cf. Alborie Livadie et al. 2005). Thus, we tested mainly the rich Iron Age funerary record in Italy that is sequenced in time using the seriation method. The Italian Iron Age ${ }^{14} \mathrm{C}$ dates are so far not very suitable for comparison with those of the southern Levant in terms of material culture, because the archaeological contexts tested do not contain imported Levantine artifacts. Nonetheless, the Italian ${ }^{14} \mathrm{C}$ results are consistent with the raised dates for the Iron Age in central Europe, which is based on dendrochronological data (see below).

Fantalkin et al. (2011) criticized almost every site we examined but ignore the fact that nearly all our ${ }^{14} \mathrm{C}$ dates correspond with a slightly higher absolute chronology for the Iron Age in Italy. The Latial phase III is characterized by the earliest imports from the eastern Mediterranean. Hence, higher (older) absolute dates for Latial phase III might also affect the absolute dates for these imports. It is clear that the older ${ }^{14} \mathrm{C}$ dates for the Iron Age in Italy are supported by those from Carthage and Huelva.

It must be emphasized that our ${ }^{14} \mathrm{C}$ research in Italy and other regions in the western Mediterranean was motivated by the ongoing debate (cf. Olde Dubbelink and van der Plicht 1989, 1990; Randsborg 1991; Peroni 1994; Giardino 1995; Bietti Sestieri 1996; Nijboer et al. 1999/2000; Bartoloni and Delpino 2005) concerning the absolute chronology of the Italian Iron Age, in view of the raised dates 
for the 9th and 8th century BCE in central Europe. Distribution patterns of specific artifacts link northern Italy and central Europe during the Late Bronze Age and Iron Age. Most of the ${ }^{14} \mathrm{C}$ results we presented for the period prior to $800 \mathrm{BCE}$ do not match the conventional absolute chronology that is based on a partial reading of Greek Geometric/Proto-Corinthian ceramics related to a text by Thucydides mentioning the Greek colonization of Sicily during the period 735-700 BC (cf. Nijboer 2005). Nonetheless, our dates make much sense in comparison to the higher dendrochronological data available for central Europe during the Late Bronze Age and Iron Age.

\section{Carthage}

In their discussion on the Carthage ${ }^{14} \mathrm{C}$ dates, Fantalkin et al. (2011) state that the date of the foundation of Carthage in 814/813 BCE, according to Timaeus of Tauromenium, took place 38 yr before the first olympiad; "Yet, dating the first olympiad is notoriously problematic" (Fantalkin et al. 2011: 182). This may be true, but the same logic applies to the basics of the conventional absolute chronology of the Greek Geometric pottery sequence, because this relies as well on a specific reading of ancient authors who wrote their stories centuries after the events took place during the 8th century BCE (cf. Coldstream 2003:233-7; Nijboer 2005:256-61, forthcoming). Concerning the historical context regarding the foundation of Carthage, see Aubet (2001:214-30), another essential reference on the western Mediterranean, which is lacking in the rejoinder by Fantalkin et al. (2011). They claim that their Low Chronology is in line with the conventional Greek chronology, referring to Coldstream (2003) (Fantalkin et al. 2011:194). However, Coldstream himself is more lenient with respect to the year of the first games at Olympia (Coldstream 2003:17-8).

We note that critical comments regarding the fundamentals of the conventional chronology for the Aegean Basin are not addressed by Fantalkin et al. (2011). They appear to imply the following inconsistent logic: the "historical" dates can be used for the conventional Iron Age chronology of the Aegean Basin but not for the Phoenicians and their exploits. Accordingly, the historical dates given by Thucydides for the foundation of early Greek colonies in southern Italy are correct while any historical date associated with the Phoenician exploits in the western Mediterranean is incorrect.

Incidentally, we never referred to the first olympiad but to Thucydides himself who wrote that the Phoenicians were already occupying coastal promontories and islets before the arrival of Greek communities on Sicily (Thuc. 6.2.6). Thus, Thucydides wrote that the Phoenicians had settled in the western Mediterranean prior to the arrival of Greek groups. This is most inconvenient for the conventional absolute chronology, as it jeopardizes its validity; therefore, these lines by Thucydides are often ignored. We seem to be left as archaeologists with 2 options with respect to the foundation of Carthage:

1. Accept the conventional absolute chronology for the Iron Age Greek ceramic sequences as a chronological marker for the Iron Age in the Mediterranean based on a system elaborated by Coldstream. Such a viewpoint is accompanied with a lower date for the foundation of Carthage, as Fantalkin et al (2011) seem to prefer. Quoting Coldstream (2003:240): "Carthage, a colony of Tyre, was the chief Phoenician outpost in North Africa, and probably the most ancient although Timeaus' date of $814 \mathrm{BCE}$ is likely to prove too early by a couple of generations."

2. Accept the foundation date of Carthage at $814 \mathrm{BCE}$, as indicated by some ancient authors and our ${ }^{14} \mathrm{C}$ dates. Such a viewpoint is accompanied by a slightly more relaxed attitude towards the conventional absolute chronology. This position is corroborated by the finds at Huelva and by other archaeological excavations revealing an early Iron Age distribution of several Levantine artifact types in some coastal regions of the western Mediterranean prior to the arrival of Euboean/Greek pottery (cf. Nijboer 2008, forthcoming). 
Concerning stratigraphy, we would have preferred ${ }^{14} \mathrm{C}$ dates of early Carthage associated within a prime archaeological context. Unfortunately, these are not available. Moreover, we presented our ${ }^{14} \mathrm{C}$ dates associated with early Carthage as a methodological test for the validity of the conventional absolute chronology. The available ${ }^{14} \mathrm{C}$ results give us a date around $800 \mathrm{BCE}$ for early settlement layers at Carthage, while the conventional absolute chronology implies a date around $750 \mathrm{BCE}$. We think that this debate can be expanded by finally testing the conventional absolute chronology for the Iron Age in Greece itself, using modern scientific dating methods. Recent dendrochronological research at Assiros in northern Greece seems to point to a higher date for the Early Iron Age in Greece (Newton et al. 2005). But since these results do not comply with the Low Chronology, Fantalkin et al. (2011:183) simply dismissed these dendrochronological dates as well.

\section{Huelva}

We have been fairly critical regarding our own ${ }^{14} \mathrm{C}$ results and their archaeological contexts in several papers. Our critical remarks were frequently quoted by Fantalkin et al. (2011) when it supported their arguments. For example, they note that we ignored Lipiński's warning that the "fleet of ships of Tarshish" is an anachronism, especially in relation to Solomon. This is a well-known fact, as mentioned by us (Nijboer and van der Plicht 2006:35). However, Lipiński does not warn that the "fleet of ships of Tarshish" is an anachronism in relation to King Hiram I of Tyre. One can consult him on the reconstructed King-list from Tyre between 950 to $774 \mathrm{BCE}$, in which he lowered the reign of Hiram I by $\sim 12$ yr to about 950-920 BC (Lipiński 2006:166-74). The fact that Lipiński can lower the years associated with the reign of King Hiram I of Tyre just provides another example of the relative character of "historic dates" in a proto-historical period, such as the Iron Age in the Mediterranean. The current High-Low chronology debate for the Iron Age in Israel is also an illustration of the ambiguous character of available "historical" and archaeological data with respect to absolute chronology; therefore, Nijboer no longer refers to decades but to periods of time that cover $25 \mathrm{yr}$. A higher resolution does not seem to be possible at the moment.

An interesting artifact type concerning Mediterranean interconnections is the Achziv-Huelva fibula that has a wide distribution (Figure 1). Fantalkin et al. (2011) dismiss a 10th century BCE date for this type of fibula. However, the 10th century BCE period is confirmed by some of the ${ }^{14} \mathrm{C}$ results listed by Sharon et al. (2007). Nijboer refers to the Achziv-Huelva fibula found at Megiddo (Loud 1948:78, plate 223; illustrated in our Figure 1, below). It pertains to Locus 2081 in area AA, square L7 that is assigned to Megiddo Stratum VA. A large amount of about 90 catalogue entries are mentioned by Loud for Locus 2081, which includes a remarkable group of cult objects such as small limestone altars (Loud 1948: plan Figure 388, p 45-6, 161-2, Figures 99-102). We suggest that the Iron Age Dating Project in future ${ }^{14} \mathrm{C}$ determinations includes the seeds that were found on the floor in front of the limestone altars, as mentioned by Loud (1948:45), if these seeds can be retraced.

Megiddo Stratum VA coincides with Early Iron IIA, which is represented in the data set of Sharon et al. (2007) by Megiddo H/5 context 3949.3 (Stratum IVB-VA). Nijboer thanks Ayelet Gilboa for her help concerning this Megiddo locus published by Loud in 1948. She confirmed in an email (9 September 2007) that this is an Early Iron IIA stratum. Amihai Mazar was so kind as to write in an email (4 November 2008):

"Locus 2081 is indeed a very important one - the major locus from Stratum IVB-VA, which stands at the heart of the whole debate on Iron Age chronology. It however belongs to the SECOND phase of Iron IIA when black on red appears (Rehov V-IV). In Rehov VI, which represents the early phase of Iron IIA, there are no black on red vessels. The BIG question is: where was the shift between these two parts of Iron IIA - after or before 900 ? This is the essence of the current debate." 

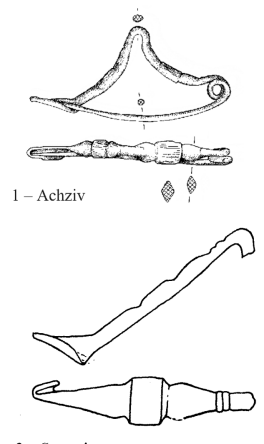

3-Samaria

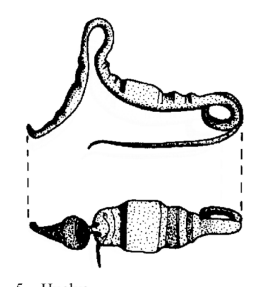

5 - Huelva
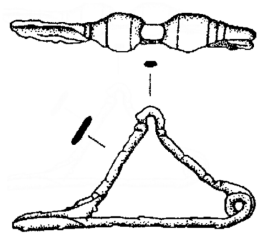

7-Cyprus, Cesnola Coll. 74.51 .5552

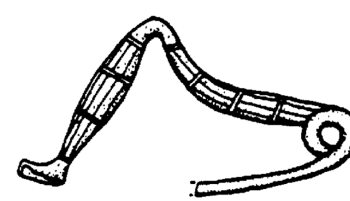

9 -Sicily, Vizzinio-Tre Canal

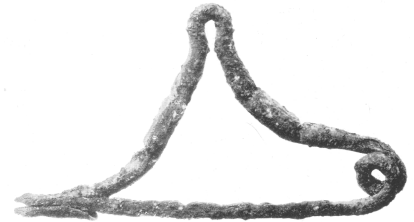

2- Megiddo

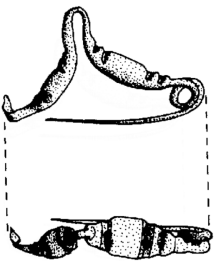

4 - Huelva

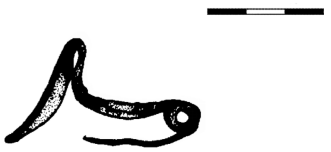

6-Huelva
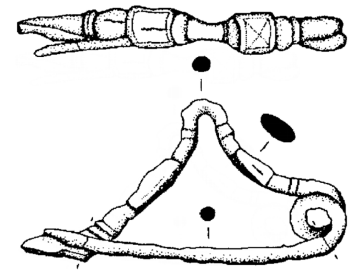

8-Cyprus, Amathus Tomb 523, 125

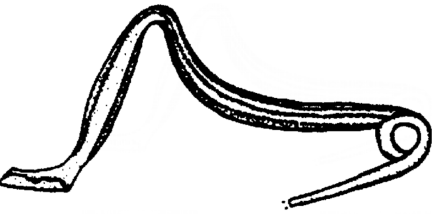

10 - Sicily, Vizzinio-Tre Canali

Figure 1 Achziv-Huelva fibula, mainly dated to the 10th century BCE (adapted from Mazar 2004:115; Loud 1948:78, plate 223; Crowfoot et al. 1957: Figure 102.1; Ruiz-Gálvez Priego 1995:241, nr. 21, 22, and 23; Giesen 2001 (Tafel 10 Idalion 180, Tafel 43, Cesnola Coll. 74.51.5552, Tafel 44, Amathus Grab 523,125); Peroni 1994:179, Figure 63.2; Giardino 1995:25A (nr 5-6 from hoard of Vizzinio-Tre Canali, Sicily, LBA-EIA).

The $4{ }^{14} \mathrm{C}$ results of seeds from Megiddo $\mathrm{H} / 5$ context 3949.3 have a weighted average of $2817 \pm 23$ BP (Sharon et al. 2007:36, Table 7), which in turn corresponds with the weighed average of the $6{ }^{14} \mathrm{C}$ results from the River Deposit at Huelva, being $2815 \pm 30 \mathrm{BP}$, also containing the Achziv-Huelva fibulae. Both sets of ${ }^{14} \mathrm{C}$ dates from Megiddo and Huelva definitely take us into the 10th century BCE. Here, we have a remarkable case of synchronism in both the ${ }^{14} \mathrm{C}$ dates and the wide distribution of a specific type of artifact. We cannot but disagree with Fantalkin et al. (2011), as they claim there is no historical significance in the above synchronism. The available ${ }^{14} \mathrm{C}$ dates from Huelva 
and Megiddo are in line with dates given for the reign of Hiram I of Tyre ( 950-920 BC), documenting early Phoenician exploits in the far West (Table 5). It is obvious that these dating results are incompatible with the Low Chronology.

Table 5 Sets of ${ }^{14} \mathrm{C}$ dates that exclude a 9 th century BCE emergence of Early Iron IIA in the southern Levant. For completeness, the somewhat younger ${ }^{14} \mathrm{C}$ data sets of Tel Rehov strata IV/VI and of the Huelva Town Deposit are also included, though they cover both the 10th and the 9th century BCE.

\begin{tabular}{|c|c|c|}
\hline Site \& context & $\begin{array}{l}\text { Weighted average }{ }^{14} \mathrm{C} \text { date } \& \\
\text { Relative archaeological age }\end{array}$ & Reference \\
\hline $\begin{array}{l}\text { Megiddo H5 (IVB- } \\
\text { VA) }\end{array}$ & $\begin{array}{l}2817 \pm 23 \mathrm{BP} \\
\text { Based on } 4{ }^{14} \mathrm{C} \text { dates } \\
\text { Early Iron IIA }\end{array}$ & Sharon et al. 2007:36 \\
\hline $\begin{array}{l}\text { Huelva, River Deposit } \\
\text { containing Achziv- } \\
\text { Huelva fibulae }\end{array}$ & $\begin{array}{l}2815 \pm 30 \mathrm{BP} \\
\text { Based on } 6{ }^{14} \mathrm{C} \text { dates } \\
\text { Final stages of the Late Bronze Age in Spain, } \\
\text { contemporaneous with Early Iron IIa in Israel. }\end{array}$ & $\begin{array}{l}\text { van der Plicht et al. 2009; } \\
\text { see above in this article }\end{array}$ \\
\hline $\begin{array}{l}\text { Tel Rehov } \\
\text { Five loci in Area D } \\
\text { Strata IV/VI }\end{array}$ & $\begin{array}{l}2870 \pm 70 \text { to } 2832 \pm 22 \mathrm{BP} \\
\text { Based on } 7{ }^{14} \mathrm{C} \text { dates. Iron IB-IIA transition } \& \\
\text { the subsequent Iron IIA strata at Tel Rehov are } \\
\text { represented by } 20^{14} \mathrm{C} \text { dates ranging from } \\
2805 \pm 15 \text { to } 2755 \pm 25 \mathrm{BP} \text {. }\end{array}$ & Bruins et al. 2007:85, 90 \\
\hline $\begin{array}{l}\text { Huelva Town Deposit } \\
\text { containing material } \\
\text { found in Tyre strata X } \\
\text { to IV }\end{array}$ & $\begin{array}{l}2755 \pm 15 \mathrm{BP} \\
\text { Based on } 3{ }^{14} \mathrm{C} \text { dates. These dates refer to the } \\
\text { Early Iron Age in this part of Spain. }\end{array}$ & $\begin{array}{l}\text { Nijboer and van der Plicht 2006; } \\
\text { van der Plicht et al. } 2009\end{array}$ \\
\hline
\end{tabular}

\section{DISCUSSION AND CONCLUSIONS}

Contrary to the reasons given by Fantalkin et al. (2011), the Tel Dan ${ }^{14} \mathrm{C}$ series is consistent, supporting a High Chronology. Moreover, Dan Stratum V (Iron Age I) and Megiddo Stratum VIA (K/4) are considered time-parallel by all authorities, including Finkelstein $(1999)$. The ${ }^{14} \mathrm{C}$ dates for Megiddo VIA (K/4) contexts 00/K/034, 00/K/008, and 98/K/032, measured in Tucson with pretreatment usually in Rehovot (Sharon et al. 2007), are very similar indeed to the Groningen ${ }^{14} \mathrm{C}$ dates for Dan Stratum V. These ${ }^{14} \mathrm{C}$ results support the archaeological age assessment by Biran (1994) of 1200-1050 BCE, but are incompatible with the Low Chronology date by Finkelstein (1999) of 1000-900 BCE for these strata. Moreover, the Megiddo VIA (K/4) dates by Sharon et al. (2007) show 3 distinct chronological phases, which requires stratigraphic reassessment of various $\mathrm{K} / 4$ contexts, as detailed above.

The rural desert site of Horvat Haluqim in the central Negev Desert contains the oldest cross-channel runoff agricultural wadi terrace so far discovered, beginning in the early 5th millennium BCE. Its use continued intermittently until Early Islamic times, including also the 2nd and 1st millennia $\mathrm{BCE}$, with clear evidence of soil manuring remains to improve soil fertility in various terrace layers. Recent excavations by Bruins and Haiman at Horvat Haluqim led to the discovery of 2 silos next to the above terrace, while flint sickle blades with gloss (typical for the Iron Age, according to S Rosen 1997; personal communication, 2010) were uncovered here as well as in the Oval Fortress. The above evidence shows the practice of runoff agriculture in the Negev Highlands during the Iron Age - contra Shahack-Gross and Finkelstein $(2008)$ - while our ${ }^{14} \mathrm{C}$ dates for Horvat Haluqim include both Iron I and Iron II dates, in chronological terms.

Concerning Tell el-Qudeirat, it is our opinion that the Oval Fortress includes Iron I and Iron II. Midianite pottery, dated by Rothenberg and Glass $(1981,1983)$ to the 13th-11th century BCE, occurs in 
the main Oval Fortress Stratum 4b, according to Bernick-Greenberg (2007). A ${ }^{14} \mathrm{C}$ date $(2930 \pm 30$ BP, GrN-12330, 1208-1055 cal BCE, $1 \sigma$ ) from the lowermost black layer in Area C, Square K6/7, supports such an age assessment, in which ${ }^{14} \mathrm{C}$ and Egyptian dates coincide.

We do not agree with the objections raised by Fantalkin et al. (2010) concerning Khirbet en-Nahas (Levy et al. 2005) and Tel Rehov (Mazar et al. 2005). Both sites do not support a Low Chronology for the Iron Age.

Early Iron IIA in the Levant is particularly important in interregional Mediterranean correlations, as Phoenician material from this period onwards is found in SW Spain, mainly at Huelva and its surrounding territory. Based on the published ${ }^{14} \mathrm{C}$ dates (Sharon et al. 2007), early Iron IIA at Megiddo dates from 1005 to $930 \mathrm{BC}(1 \sigma)$ while at Tel Dor it dates from 920 to $840 \mathrm{BC}(1 \sigma)$. Sharon et al. (2007) consider all $4{ }^{14} \mathrm{C}$ dates from Megiddo, relating to this early Iron IIA context, as outliers. However, the ${ }^{14} \mathrm{C}$ dates from all phases at Megiddo are consistently higher than those from Tel Dor. One could also argue the other way round, that the ${ }^{14} \mathrm{C}$ dates from Tel Dor are the outliers.

Greek Geometric ceramics are present in the western Mediterranean from $\sim 800$ BC onwards (cf. Nijboer, forthcoming). This leaves a considerable gap in time between the Iron Age Levantine artifacts in the western Mediterranean and the Greek 8th century BCE ceramics. This position is confirmed by new dendrochronological data provided by the Aegean Dendrochronology Project at Cornell (cf. Manning et al. 2001; De Vries et al. 2003; Newton et al. 2005; Nijboer 2005:265-6). Moreover, dendrochronological data from central Europe give considerably higher absolute years for the beginning of the Iron Age (cf. Pare 1996, 1998, 2000; Friedrich and Hennig 1996; Trachsel 2004). The above dendrodates, supporting a higher chronology for the Iron Age in the Mediterranean, and beyond, are not addressed in the rejoinder by Fantalkin et al. (2011). These dendrodates also support the Italian ${ }^{14} \mathrm{C}$ sequence provided by van der Plicht et al. (2009), which was dismissed by Fantalkin et al. It would have been to the credit of Fantalkin et al. (2011) if they would have evaluated their own data set with the same criteria as they examined ours.

Sharon et al. (2007) attempt to find an average date for early Iron IIA in the southern Levant, but without discussing the consistent discrepancies of the ${ }^{14} \mathrm{C}$ results per site. This severe problem was evaluated by us for the Iron I Stratum of Megiddo VIA (K/4). Indeed, the erroneous averaging of higher dates with lower dates that are internally incompatible, possibly due to invalid site stratigraphies, can lead to a lower average chronology. Sharon et al. (2007:12) noted that mean values are a simplification. However, it becomes a mistaken oversimplification when one can detect consistent differences between ${ }^{14} \mathrm{C}$ sequences per site, such as between Tel Dor and Megiddo. Indeed, the Tel Dor ${ }^{14} \mathrm{C}$ sequence remains at the heart of the Low Chronology hypothesis, but this sequence remains also the most problematic.

We prefer a single-site approach with detailed analysis of both stratigraphy and dating results, rather than a simplified averaging of dates from many sites taken together, in which matters become nontransparent and results may be misinterpreted to a considerable extent.

\section{REFERENCES}

Albore Livadie C, Bartoli C, Boenzi G, Cicirelli C, Guzzo PG. 2005. The Poggiomarino River settlement in the Longola area. In: Attema P, Nijboer AJ, Zifferero A, editors. Papers in Italian Archaeology VI, Communities and Settlements from Neolithic to the Early Medieval Period. Proceedings of the 6th Conference of Italian Archaeology held at the University of Groningen,
15-17 April 2003. BAR International Series 1452 (II). Oxford: Archaeopress. p 699-705.

Aubet ME. 2001. The Phoenicians and the West. Cambridge: Cambridge University Press.

Avni G, Avni Y, Porat N. 2009. A new look at ancient agriculture in the Negev. Cathedra 133:13-44. In Hebrew. 
Bartoloni G, Delpino F, editors. 2005. Oriente e Occidente: metodi e discipline a confronto. Riflessioni sulla cronologia dell'età del ferro in Italia, Atti dell'Incontro di studi, Roma, 30-31 ottobre 2003. Mediterranea, 1 (2004). Pisa: Istituti Editoriali e Poligrafici Internazionali.

Ben-Tor A. 2000. Hazor and the chronology of northern Israel: a reply to Israel Finkelstein. Bulletin of the American Schools of Oriental Research 317:9-15.

Bernick-Greenberg H. 2007. The ceramic assemblages and the wheel-made pottery typology. In: Cohen R, Bernick-Greenberg H. Excavations at Kadesh Barnea (Tell el-Qudeirat) 1976-1982. Part 1. IAA Reports 34/1. Jerusalem: Israel Antiquities Authority. p 13185 .

Bienkowski P. 2001. The Iron Age and Persian periods in Jordan. Studies in the History and Archaeology of Jordan VII:265-74.

Bietti Sestieri AM. 1996. Protostoria: teoria e pratica. Roma: La Nuova Scientifica.

Biran A. 1994. Biblical Dan. Jerusalem: Israel Exploration Society.

Boaretto E, Finkelstein I, Shahack-Gross R. 2010. Radiocarbon results from the Iron IIA site of Atar Haroa in the Negev Highlands and their archaeological and historical implications. Radiocarbon 52(1):1-12.

Bronk Ramsey C. 2001. Development of the radiocarbon calibration program. Radiocarbon 43(2A):355-63.

Bronk Ramsey C. 2005. OxCal Program v 3.10. Radiocarbon Accelerator Unit, University of Oxford.

Bronk Ramsey C, Dee MW, Higham TFG, Harris SA, Brock F, Quiles A, Wild EM, Marcus ES. 2010. Radiocarbon-based chronology for Dynastic Egypt. Science 328(5985): 1554-7.

Bruins HJ. 1990. Ancient agricultural terraces at Nahal Mitnan. Atiqot 10:127-8 (Hebrew); 22*-28* (English).

Bruins HJ. 2003. Man and landscape in the Negev Highlands: runoff systems. Ofaqim BeGeografia 57-58: 146-58. In Hebrew.

Bruins HJ. 2005. Ancient agriculture in the Negev: the soil as an archaeological and environmental archive. In: Ackermann O, Faust A, Maeir A, editors. Archaeology and Environment. Conference Proceedings, The Martin (Szusz) Department of Land of Israel Studies and Archaeology, Bar-Ilan University, Ramat Gan. p 171-7. In Hebrew.

Bruins HJ. 2007. Runoff terraces in the Negev Highlands during the Iron Age: nomads settling down or farmers living in the desert? In: van der Steen EJ, Saidel BA, editors. On the Fringe of Society: Archaeological and Ethnoarchaeological Perspectives on Pastoral and Agricultural Societies. BAR International Series 1657. Oxford: Archaeopress. p 37-43.

Bruins HJ. 2010. Dating Pharaonic Egypt. Science 328(5985):1489-90.

Bruins HJ, van der Plicht J. 2003. Assorting and synchro- nising archaeological and geological strata with radiocarbon: the southern Levant in relation to Egypt and Thera. In: Bietak M, editor. The Synchronisation of Civilizations in the Eastern Mediterranean in the $2^{\text {nd }}$ millennium BC - II. Vienna: Austrian Academy of Sciences. p 35-42.

Bruins HJ, van der Plicht J. 2004. Desert settlement in the central Negev: first ${ }^{14} \mathrm{C}$ indication of rainwater-harvesting agriculture in the Iron Age. In: Higham TFG, Bronk Ramsey C, Owen DC, editors. Radiocarbon and Archaeology: Proceedings of the 4th International Symposium, Oxford, 2002. Oxford: Oxford University, School of Archaeology, Monograph 62. p 83-98.

Bruins HJ, van der Plicht J. 2005. Desert settlement through the Iron Age: radiocarbon dates from Sinai and the Negev Highlands. In: Levy TE, Higham T, editors. The Bible and Radiocarbon Dating: Archaeology, Text and Science. London: Equinox. p 349-66.

Bruins HJ, van der Plicht J. 2007. Radiocarbon dating the "Wilderness of Zin." Radiocarbon 49(2):481-97.

Bruins HJ, Evenari M, Nessler U. 1986. Rainwater-harvesting agriculture for food production in arid zones: the challenge of the African famine. Applied Geography 6:13-32.

Bruins HJ, van der Plicht J, Mazar A. 2003a. ${ }^{14} \mathrm{C}$ dates from Tel Rehov: Iron-Age chronology, pharaohs and Hebrew kings. Science 300(5617):315-8.

Bruins HJ, van der Plicht J, Mazar A. 2003b. Response to Comment on " ${ }^{14} \mathrm{C}$ dates from Tel Rehov: Iron-Age chronology, Pharaohs and Hebrew Kings." Science 302(5645):568

Bruins HJ, van der Plicht J, Ilan D, Werker E. 2005a. Iron-Age ${ }^{14} \mathrm{C}$ dates from Tel Dan: a high chronology. In: Levy TE, Higham T, editors. The Bible and Radiocarbon Dating: Archaeology, Text and Science. London: Equinox. p 323-36.

Bruins HJ, van der Plicht J, Mazar A, Bronk Ramsey C, Manning SW. 2005b. The Groningen radiocarbon series from Tel Rehov: OxCal Bayesian computations for the Iron IB-IIA Boundary and Iron IIA destruction events. In: Levy TE, Higham T, editors. The Bible and Radiocarbon Dating: Archaeology, Text and Science. London: Equinox. p 271-93.

Bruins HJ, Mazar A, van der Plicht J. 2007. The end of the 2nd millennium BCE and the transition from Iron I to Iron IIA: radiocarbon dates of Tel Rehov, Israel. In: Bietak M, Czerny E, editors. The Synchronisation of Civilisations in the Eastern Mediterranean in the Second Millennium B.C. - III. Vienna: Austrian Academy of Sciences. p 79-99.

Cohen R. 1976. Excavations at Horvat Haluqim. Atiqot 11:34-50.

Cohen R, Cohen-Amin R. 2004. Ancient Settlement of the Negev Highlands Volume II. The Iron Age and the Persian Periods. IAA Reports 20. Jerusalem: Israel Antiquities Authority.

Cohen R, Bernick-Greenberg H. 2007. Excavations at 
Kadesh Barnea (Tell el-Qudeirat) 1976-1982. IAA Reports 34. Jerusalem: Israel Antiquities Authority.

Coldstream JN. 2003. Geometric Greece: 900-700 BC. London: Routledge.

Crowfoot JW, Crowfoot GM, Kenyon KM. 1957. The Objects of Samaria. London: Palestine Exploration Fund.

Dar S. 1986 Hirbet Jemein — a first temple village in western Samaria. In: Dar S, Safrai Z, editors. Shomron Studies. Tel Aviv: Hakibbutz Hameuchad p 13-73. In Hebrew.

De Vries K, Kuniholm PI, Sams GK, Voigt MM. 2003. New dates for Iron Age Gordion. Antiquity 77(296): Project Gallery. http://www.antiquity.ac.uk/projgall/ devries296/.

Edelstein G, Kislev M. 1981. Mevasseret Yerushalayim: the ancient settlement and its agricultural terraces. The Biblical Archaeologist 44(1):53-6.

Evenari M, Shanan L, Tadmor N. 1982. The Negev-The Challenge of a Desert. Cambridge: Harvard University Press.

Fantalkin A, Finkelstein I, Piasetzky E. 2011. Iron Age Mediterranean chronology: a rejoinder. Radiocarbon 53(1):179-98.

Faust A. 2000. The rural community in ancient Israel during Iron Age II. Bulletin of the American Schools of Oriental Research 317:17-39.

Finkelstein I. 1984. The Iron Age fortresses of the Negev Highlands: sedentarization of desert nomads. Tel Aviv 11:189-209.

Finkelstein I. 1986. The Iron Age sites in the Negev Highlands - military fortresses or nomads settling down. Biblical Archaeology Review 12:46-53.

Finkelstein I. 1995. Living on the Fringe. Sheffield: Sheffield Academic Press Monographs in Mediterranean Archaeology.

Finkelstein I. 1996. The archaeology of the United Monarchy: an alternative view. Levant 28:177-87.

Finkelstein I. 1999. Hazor and the north in the Iron Age: a low chronology perspective. Bulletin of the American Schools of Oriental Research 314:55-70.

Finkelstein I. 2005. Khirbet en-Nahas, Edom and Biblical History. Tel Aviv 32:119-25.

Finkelstein I. 2010. Kadesh Barnea: a reevaluation of its archaeology and history. Tel Aviv 37:111-25.

Finkelstein I, Piasetzky E. 2003. Recent radiocarbon results and King Solomon. Antiquity 77(298):771-9.

Finkelstein I, Piasetzky E. $2006 .{ }^{14} \mathrm{C}$ and the Iron Age chronology debate: Rehov, Khirbet en-Nahas, Dan, and Megiddo. Radiocarbon 48(3):373-86.

Finkelstein I, Piasetzky E. 2008. Radiocarbon and the history of copper production at Khirbet en-Nahas. Tel Aviv 35:82-95.

Finkelstein I, Piasetzky E. 2010. The Iron I/IIA transition in the Levant: a reply to Mazar and Bronk Ramsey and a new perspective. Radiocarbon 52(4):1667-80.

Finkelstein I, Ussishkin D, Halpern B. 2008. Megiddo.
In: The New Encyclopedia of Archaeological Excavations in the Holy Land. Volume 5. Jerusalem: Israel Exploration Society. p 1944-50.

Franken HJ, Franken-Battershill CA. 1963. A Primer of Old Testament Archaeology. Leiden: Brill.

Friedrich M, Hennig H. 1996. Dendrodate for the Wehringen Iron Age wagon grave (778 +/-5 BC). Journal of European Archaeology 4:281-303.

Giardino C. 1995. Il Mediterraneo Occidentale fra XIV ed VIII secolo a.C.; Cerchie minerarie e metallurgia. BAR International Series 612. Oxford: Archaeopress.

Giesen K. 2001. Zyprische Fibeln, Typologie und Chronologie. Jonsered: Paul Åströms Förlag.

Gilead I. 2007. The Besorian: a pre-Ghassulian cultural entitiy. Paléorient 33(1):33-49.

Haiman M. 1994. The Iron Age II sites of the western Negev Highlands. Israel Exploration Journal 44:36-61.

Higham T, van der Plicht J, Bronk Ramsey C, Bruins HJ, Robinson M, Levy TE. 2005. Radiocarbon dating of the Khirbat-en Nahas site (Jordan) and Bayesian modeling of the results. In: Levy TE, Higham T, editors. The Bible and Radiocarbon Dating: Archaeology, Text and Science. London: Equinox. p 164-78.

Ilan D. 1999. Northeastern Israel in the Iron Age I: cultural, socioeconomic and political perspectives $[\mathrm{PhD}$ thesis]. Tel Aviv University.

Lavee H, Imeson AC, Sarah P. 1998. The impact of climate change on geomorphology and desertification along a Mediterranean arid transect. Land Degradation \& Development 9:407-22.

Levy TE, Adams RB, Muniz A. 2004. Archaeology and the Shasu nomads: recent excavations in the Jabal Hamrat Fidan, Jordan. In: Propp WHC, Friedman RE. Le-David Maskil: A Birthday Tribute for David Noel Freedman. Winona Lake: Eisenbrauns. p 63-89.

Levy TE, Najjar M. 2006. Some thoughts on Khirbet enNahas, Edom, biblical history and anthropology - a response to Israel Finkelstein. Tel Aviv 33:3-17.

Levy TE, Najjar M, van der Plicht J, Higham T, Bruins HJ. 2005. Lowland Edom and the high and low chronologies: Edomite state formation, the Bible and recent archaeological research in southern Jordan. In: Levy TE, Higham T, editors. The Bible and Radiocarbon Dating: Archaeology, Text and Science. London: Equinox. p 129-63.

Levy TE, Higham T, Bronk Ramsey C, Smith NG, BenYosef E, Robinson M, Munger S, Knabb K, Schulze JP, Najjar M, Tauxe L. 2008. High-precision radiocarbon dating and historical biblical archaeology in southern Jordan. Proceedings of the National Academy of Sciences 105(43):16,460-5.

Loud G. 1948. Megiddo II, Seasons of 1935-39. Chicago: The University of Chicago Press.

Lipiński E. 2006. On the skirts of Canaan in the Iron Age. Orientalia Lovaniensia Analecta 153. Leuven: Peeters.

Manning SW, Kromer B, Kuniholm PI, Newton MW. 
2001. Anatolian tree rings and a new chronology for the east Mediterranean Bronze-Iron Ages. Science 294(5551):2532-5.

Mazar A. 2003. The excavations at Tel Rehov and their significance for the study of the Iron Age in Israel. Eretz Israel 27:143-60. In Hebrew.

Mazar A. 2004. Greek and Levantine Iron Age chronology: a rejoinder. Israel Exploration Journal 54:24-36.

Mazar A, Bronk Ramsey C. $2008 .{ }^{14} \mathrm{C}$ dates and the Iron Age chronology of Israel: a response. Radiocarbon 50(2):159-80.

Mazar A, Bronk Ramsey C. 2010. A response to Finkelstein and Piasetzky's criticism and "new perspective." Radiocarbon 52(4):1681-8.

Mazar A, Bruins H, Panitz-Cohen N, van der Plicht J. 2005. Ladder of time at Tel Rehov: stratigraphy, archaeological context, pottery and radiocarbon dates. In: Levy TE, Higham T, editors. The Bible and Radiocarbon Dating: Archaeology, Text and Science. London: Equinox. p 193-255.

Newton M, Wardle KA, Kuniholm PI. 2005. Dendrochronology and radiocarbon determinations from Assiros and the beginning of the Greek Iron Age. Conference of Archaeological Research in Macedonia \& Thrace, Proceedings, Thessaloniki. Available at http:/ /dendro.cornell.edu/articles/newton2005.pdf. p 17390.

Nijboer AJ. 2005. The Iron Age in the Mediterranean: a chronological mess or 'trade before the flag', part II. Ancient West and East 4:254-77.

Nijboer AJ. 2008. Italy and the Levant during the Late Bronze and Iron Age. In: Sagona C, editor. Beyond the Homeland: Markers in Phoenician Chronology. Leuven: Peeters. p 357-94.

Nijboer AJ. Forthcoming. Teleology and colonisation in antiquity and in recent times. Ancient West \& East 2010/2011.

Nijboer AJ, van der Plicht J. 2006. An interpretation of the radiocarbon determinations of the oldest indigenous-Phoenician stratum thus far, excavated at Huelva, Tartessos (south-west Spain). BABESCH Annual Papers on Mediterranean Archaeology 81:41-6.

Nijboer AJ, van der Plicht J, Bietti Sestieri AM, De Santis A. 1999/2000. A high chronology for the early Iron Age in Central Italy. Palaeohistoria 41/42:163-76.

Olde Dubbelink RA, van der Plicht J. 1989. Satricum en de 14C-datering. Tijdschrift voor Mediterrane Archeologie 4:4-13.

Olde Dubbelink RA, van der Plicht J. 1990. Le Capanne II e IV a Borgo le Ferriere (Satricum) e le datazione al radiocarbonio, Archeologia Laziale X. Rome: Quaderni di Archeologia Etrusco-Italica 19, CNR. p 234-7.

Pacciarelli M. 1999. Torre Galli: La necropoli della prima età del Ferro. Catanzaro: Rubbettino.

Pare C. 1996. Chronology in Central Europe at the end of the Bronze Age. Acta Archaeologica (København) 67: 99-120.

Pare C. 1998. Beiträge zum Übergang von der Bronze- zur Eisenzeit in Mitteleuropa, Teil I: Grundzüge der Chronologie im östlichen Mitteleuropa (11.-8. Jahrhundert v. Chr.). Jahrbuch des Römisch-Germanischen Zentralmuseums Mainz 45, 1998 (1999):293433.

Pare C. 2000. Beiträge zum Übergang von der Bronzezur Eisenzeit in Mitteleuropa, Teil II: Grundzüge der Chronologie im westlichen Mitteleuropa (11.-8. Jahrhundert v. Chr.). Jahrbuch des Römisch-Germanischen Zentralmuseums Mainz 46, 1999 (2000):175315.

Peroni R. (1994) Introduzione alla protostoria Italiana. Roma: Editori Laterza.

Porter BW. 2004. Authority, polity, and tenuous elites in Iron Age Edom (Jordan). Oxford Journal of Archaeology 23:373-95.

Randsborg K. 1991. Historical implications; chronological studies in European archaeology c. 2000-500 BC. Acta Archeologica 62. København. p 89-109.

Reimer PJ, Baillie MGL, Bard E, Bayliss A, Beck JW, Bertrand CJH, Blackwell PG, Buck CE, Burr GS, Cutler KB, Damon PE, Edwards RL, Fairbanks RG, Friedrich M, Guilderson TP, Hogg AG, Hughen KA, Kromer B, McCormac G, Manning S, Bronk Ramsey C, Reimer RW, Remmele S, Southon JR, Stuiver M, Talamo S, Taylor FW, van der Plicht J, Weyhenmeyer CE. 2004. IntCal04 terrestrial radiocarbon age calibration, 0-26 cal kyr BP. Radiocarbon 46(3):1029-58.

Rosen S. 1997. Lithics after the Stone Age: Handbook of Stone Tools from the Levant. Walnut Creek: AltaMira Press.

Rosen S. 2006. The desert and the sown: A lithic perspective. In: Eriksen BV, editor. Lithic Technology in Metal Using Societies. Højbjerg: Jutland Archaeological Society Publications Volume 67. p 203-19.

Rothenberg B. 1972. Timna. London: Thames and Hudson.

Rothenberg B. 1988. The Egyptian Mining Temple at Timna. London: IAMS.

Rothenberg B, Glass J. 1981. Midianite pottery. Eretz Israel 15:85-114. In Hebrew with English summary.

Rothenberg B, Glass J. 1983. The Midianite pottery. In: Sawyer JFA, Clines DJA, editors. Midian, Edom and Moab: The History and Archaeology of Late Bronze and Iron Age Jordan and North-West Arabia. JSOT Supplement 24, Sheffield. p 65-124.

Ruiz-Gálvez Priego M, editor. 1995. Ritos de Paso y Puntos de Paso. La Ría de Huelva en el Mundo del Bronce Final Europeo. Complutum extra 5. Madrid: Servicio de Publicationes Universidad Complutense.

Sciacca F. Forthcoming. Commerci fenici nel Tirreno orientale: uno sguardo dalle grandi necropoli, in $\mathrm{Pa}$ pers XVII Congresso Internazionale di Archeologia Classica; Incontri tra Culture nel Mondo Mediterraneo Antico. Rome, Palazzo della FAO, 22-26 September 2008. Bollettino di Archeologia. http:// 151.12.58.75/archeologia/index.php?option $=$ com_content\&view $=$ article $\&$ id $=2 \&$ Itemid $=2$. 
Shahack-Gross R, Finkelstein I. 2008. Subsistence practices in an arid environment: a geoarchaeological investigation in an Iron Age site, the Negev Highlands, Israel. Journal of Archaeological Science 35(4):96582.

Sharon I, Gilboa A, Jull TAJ, Boaretto E. 2007. Report on the first stage of the Iron Age Dating Project in Israel: supporting a Low Chronology. Radiocarbon 49(1):146.

Shiloh Y. 1993. Megiddo. In: The New Encyclopedia of Archaeological Excavations in the Holy Land. Volume 3. New York: Simon \& Schuster; Jerusalem: The Israel Exploration Society. p 1003-24.

Shor P, Bernick-Greenberg H. 2007. Area C: the eastcentral part of the Strata 3-2 courtyard. In: Cohen R, Bernick-Greenberg H. Excavations at Kadesh Barnea (Tell el-Qudeirat) 1976-1982. IAA Reports 34. Jerusalem: Israel Antiquities Authority. p 67-85.

Singer-Avitz L. 2008. The earliest settlement at Kadesh Barnea. Tel Aviv 35:73-81.

Stager LE. 1982. The archaeology of the East Slope of Jerusalem and the terraces of the Kidron. Journal of Near Eastern Studies 41(2):111-21.

Trachsel M. 2004 Untersuchungen zur relativen und $a b-$ soluten Chronologie der Hallstattzeit. Bonn: Universitätsforschungen zur Prähistorischen Archäologie 104.

van der Plicht J, Bruins HJ. 2001. Radiocarbon dating in Near-Eastern contexts: confusion and quality control. Radiocarbon 43(3):1155-66.

van der Plicht J, Bruins HJ. 2005. Quality control of Groningen ${ }^{14} \mathrm{C}$ results from Tel Rehov: repeatability and intercomparison of proportional gas counting and AMS. In: Levy TE, Higham T, editors. The Bible and Radiocarbon Dating: Archaeology, Text and Science. London: Equinox. p 256-70.

van der Plicht J, Wijma S, Aerts AT, Pertuisot MH, Meijer HAJ. 2000. Status report: the Groningen AMS facility. Nuclear Instruments and Methods B 172(14):58-65.

van der Plicht J, Bruins HJ, Nijboer AJ. 2009. The Iron Age around the Mediterranean: a High Chronology perspective from the Groningen radiocarbon database. Radiocarbon 51(1):213-42.

Wilkinson TJ. 1989. Extensive sherd scatters and landuse intensity: some recent results. Journal of Field Archaeology 16(1):31-46. 